\title{
The Other Face of Augustus's Aggressive Inclination to Egypt
}

\author{
Wahid Omran \\ Lecturer in Tourist Guidance Dep., Faculty of Tourism and Hotels, Fayoum University
}

\section{Introduction}

The initial attitude of Octavian against Egypt is proved by his speech to his troops on the evening before the battle of Actium. Pride in his Roman birth is compared to the despicability of an Egyptian woman as an opponent, who is supported by Dio Cassius reference. ${ }^{1}$

"Alexandrians and Egyptians- what worse or what truer name could one apply to them?- who worship reptiles and beasts as gods, who embalm their own bodies to give them semblance of immortality, who are most reckless in effrontery but most feeble in courage, and worst of all are slaves to a woman and not to a man".

Since The Roman poet Virgile (70- 19 B.C), ${ }^{2}$ the Romans opposed the animal - cult of the Egyptians, and considered these gods as monsters. ${ }^{3}$ The Egyptian character of the Augustus's opponents is related to the Augustan propaganda, represented the Augustus's war against Antony and Cleopatra not only a civil war between Rome and Egypt, but like a struggle between the West and the East. Whose Mark Antony was a traitor joined the powers of the East, whereas Octavian's victory in Actium was not only for himself, but basically for Rome and the Romans. This struggle was described in literature's documents as a civil strife or a foreign war. ${ }^{4}$

Augustus also knew he had a compensated war against Antony and Cleopatra as a republican magistrate crushing Oriental despotism. ${ }^{5} \mathrm{He}$ is supported by the Roman society ethics and the star of the sacred Caesar, on the other hand, Antony, once a great Roman commander-in-chief, but now supported by a foreign army and followed by unnamed Egyptian spouse. ${ }^{6}$

The Romans considered the battle not only a military, but either a religious one between the Roman and the Egyptian Pantheons. The Romans mocked of the Egyptian deities and considered them as enemies. Therefore, during this war, Antony was under the homage of these anthropomorphic Egyptian gods as Isis, Osiris, Serapis and Anubis, while Cleopatra called up her troops by using the ancient sistrum, one of the attributes of Isis cult. ${ }^{7}$ While, the Roman gods support Octavian. The Roman abhorrence of Egyptian theomorphic gods created a hostile feeling towards Antony and Cleopatra. ${ }^{8}$

The Roman poets related to the Octavian's war, mainly considered Alexandria, Canopus and Memphis as symbols of the various vices of which they accused the Egyptians. Alexandria was the capital, the cosmopolitan city, and the important trade harbor in the Mediterranean, Canopus as an entertainment center, while Memphis was the capital for the native Egyptians. This is described as a city of the barbarian, guilty of the blood of the Romans, and mocking on its religious significance for the Egyptians. ${ }^{9}$

The fall of "the Egyptian wife of the Roman leader" led Ovid to follow this by ridiculing her threats to put the Capitol in subservience to Canopus. ${ }^{10}$ Again, while talking about "the queen of Canopus" Propertius mentioned, ${ }^{11}$ in the same poem, Alexandria and Memphis, in direct mention to Egypt. While denouncing what he considered the queen's preposterous contrast between Jupiter and Anubis, the Tiber and the Nile, the Roman horn and the sistrum of Isis. Vergil talked about "Antony's Egyptian wife", "the queen calling her forces with the sistrums of her fatherland", and "the mournful Nile", while contrasting the Egyptian and the Roman deities. ${ }^{12}$ The other face of Augustus's Preference against Egypt can be well- noticed in these four points:

\section{- The Imperial Cult "Kaisareion"}

The imperial cult was a system rose from the Roman provinces, not from Rome itself, especially in Asia Minor. Later, it flourished and spread to all the Roman provinces. ${ }^{13}$ The cult of the genius of Augustus became a principal element in Italy during his lifetime. ${ }^{14}$ The Republican Rome know the imperial cult, as a maintenance of the cults given to Roman leaders, both political and military, either out of the genuine gratitude for benefactions conferred, or form of a sycophantic desire to do favor with the leaders at Rome, especially the great generals of the Late Republican history. ${ }^{15}$ Divine honors, including festivals, were decreed on behalf of such Roman leaders such as Sulla, Pompey and Julius Cesar. In addition to these cults, the Romans regarded goddess "Roma" as the symbol of "the entire Roman people", or of "the Roman state". ${ }^{16}$ Therefore, the chief priest of the imperial cult of Augustus at Rome was "chief priest of the goddess Roma and the emperor Caesar, son of god, Augustus". ${ }^{17}$

By seizing Egypt after the battle of Actium in 30 B. C, Augustus succeeded the Ptolemies and their predecessor, the Egyptian Pharaohs. He established a new Roman cult not only in Egypt, but in the whole world. The Egyptians worshipped Roman emperors and portrayed them traditionally on Egyptian temple relief, ${ }^{18}$ and the worship of the living emperor as well as the dead one.

The emperor became fully integrated to the Egyptian gods in their temples like the Ptolemies, the emperor automatically became "synnaoi" of the Egyptian gods, as a continuation of the Ptolemaic cult. ${ }^{19}$ However, the Roman 
cult was locally organized on the level of the Greek poleis (especially Alexandria) and the nomemetropoleis, the organization of the cult was "official", and the living emperors didn't receive divine cult name as the Ptolemies, since Augustus was given an official cult name as "Zeus Eleutherios Sebastos". ${ }^{20}$ In addition, his imperial statues were not typical cult statues, they were of Hellenistic style. ${ }^{21}$

Festivals and rituals performed in temples in honor of the emperors. ${ }^{22}$ The Egyptian priests didn't play any role in the Imperial cult, unlike the Ptolemaic royal cult. In 30 B.C, when Augustus was still known as Octavian conquered Alexandria, the ascension of Octavian to the Egyptian throne took place on Thot I Egyptian in 29 B.C= August 31 Julian 29 B.C, ${ }^{23}$ he decided to annex Egypt as a province of Rome. In fact, Egypt was both a gold mine and a granary to the Roman soldiers as well as a spring-board to the Roman conquerors in their campaigns in the East. ${ }^{24}$ After Actium battle, the appearance of Augustus in Alexandria, and his brief stay in Egypt and the events during these days, refered to the beginning of a new era in Egypt, and illustrate the personal prejudices of the Roman Augustus towards Egypt, the Egyptians, and their cults. These events were related by Dio Cassius as follows:

"He was merciful toward all the Egyptians and Alexandrians and had none of them put to death. In reality, this was because he did not want to inflict any irreparable harm on them because they were numerous and might be useful to the Romans in many ways. As enexcuse, however, he cited their god Serapis and their founder Alexander, as well as their fellow citizen Arius, with whom he was on intimate terms and liked to discuss Philosophy. The speech in which he proclaimed his pardon gor them he delivered in Greek, so that they could understand him. It is said that when he later viewed the body of Alexander, he touched it, breaking off a bit of the nose in the process. However, he did not view the bodies of the Ptolenmies, although the Alexandrians were eager to show them to him, and he declared, "It was a king I wished to see, not corpses". And for this same reason he refused to make a visit to see the Apis bull, stating that he was accustomed to worship gods but not cattle".

Augustus in his few days in Egypt, and his first years of rule, was confused under a contradiction between his malice and hatred of Cleopatra VII, not only his rival enemy, but either the Romans'. Besides, his eagerness to maintain his Roman blood and traditions as a Caesar, he seized Alexandria as a present for the Romans. He succeeded to achieve the holy victory, especially his first pseudo-god treatment and attitude towards the Egyptians was not because of his love or sympathy with them, but of their large numbers and they might be useful to the Romans in several aspects, as Cassius mentioned. This first attitude remained in a power struggle with his Personal aspirations and dreams as a pharaoh, as a hero, as a legendary figure, or as a god. The clash was between the imposed and the hoped -selfish attitude of Augustus; he accepted his divinity in Egypt, recognizing that religion was an essential tool for gaining Egyptian support in ruling the area.

Augustus granted Egypt a special status among all his conquered provinces. According to Roman tradition; only a person of senatorial rank could be appointed to govern a province of the Roman Empire, due to the importance and the great rank of Egypt as the main granary of Rome and the Romans. Augustus broke this tradition by appointing Gallus as the prefect of Egypt, as described by Dio Cassiusas, ${ }^{25}$

"Afterwards he made Egypt tributary and gave it in charge of Cornelius Gallus. For in view of the populousness of both the cities and country, the facile, fickle character of the inhabitants, and the extent of the grainsupply and of wealth, so far from daring to entrust the land to any senator, he would not even grant a senator permission to live in it, expect as he personally made the concession to him by name".

This fact is also confirmed by Tacitus, ${ }^{26}$ who pointed out that "Egypt was economically so rich and strategically so secure that it would have been dangerous to place it under a senator who might be tempted to rebel"

Augustus intended to follow Alexander the Great's steps, and to be a deified character either. Augustus invented a birth legend, as Alexander the Great had done, as one of the Pharaohs' descendants, Nechtanebo II take the form of a serpent in the form of Amun, and spent the night with Alexander's mother Olympius. ${ }^{27}$

Augustus's birth legend was recited by Alexander's historian, Pseudo- Kallisthenes. ${ }^{28}$ Sueton $^{29}$ and Dio Cassius rumored the Augustus's birth legend, that Augustus's mother "Atia" spent the nights in the temple of Apollo, during a night god Apollo has the form of a serpent and spent his night with her, and then Augustus was born. While he was a ten- months old child; he was known by the Romans as "Son of Apollo", a clear allusion to the birth of Alexander. Nigidius Figulus, the astrologer, had announced at the hour of Augustus's birth that the ruler of the world had been born. $^{30}$

In Rome, he was known as "the new Alexander", and "the son of Apollo". ${ }^{31}$ Another legend attributed to Augustu's father, on a campaign in Thrace, stopped to ask the high priest of the temple of Liber Pater/ Dionysos, regarding his son, while he made sacrifices, the fire of the sacrifices rose up till the heaven, and the high priest of the temple proclaimed that Augustus is the "New Alexander" real son of Apollo, the same was done before with Alexander the Great, and the same risen flame to the heaven appeared before when Alexander offered sacrifice upon this same altar. $^{32}$

At various times and in various ways, Augustus was admired of both the character and personality of Alexander the Great. His behavior pointed what is called "aemulatio Alexandri". ${ }^{33}$ He used a portrait of Alexander on 
his official seal during the early years of his reign. He appeared in his coins-figures as Alexander portraits. ${ }^{34}$ Augustus visited the tomb of Alexander the Great in Alexandria, and paid his respect to Alexander as a great conqueror, Alexander was above all a role model for Augustus. He put flowers and gold crown upon his body, but he refused to visit the tombs of the Ptolemies. Dio Cassius referred that Augustus had said "He wants to visit kings, not the dead ones". The Augustus's refuse of visiting the Ptolemies tombs, indicates he was intended to be the new king, and the heir of Alexander and the Ptolemies on Egypt's throne. Instead, he was a successor to Alexander as world conqueror and either ruler.

Sueton described Augustus as "the son of the Egyptian gods". While Dio Cassius described him as the "the expected ruler of the world". Augustus's mother "Atia" dreamed that her guts were lifted up to the stars and spread over heaven and earth. While Augustus's father dreamed that sun radiations and rays are coming up from his wife's womb. ${ }^{35}$

Like Alexander, Augustus subsequently visited Memphis; where the god Ptah and the Apis bull had been revered since the $1^{\text {st }}$ dynasty. Both of them were responsible for the coronation of the Ptolemaic kings, ${ }^{36}$ but nothing is known about an Egyptian coronation of Augustus as Egyptian Pharaoh like Alexander, which made his recognition by the Senate impossible, that he was still only a representative of the Roman state provided with special powers, he wanted to consolidate his statue at Rome, ${ }^{37}$ was maybe crowned as a Roman Caesar there. ${ }^{38}$ This gives the connection between the birth of Augustus and the solar cult in Egypt, and the journey of the Sun-god Re in the sky at the night to be reborn again in the morning from the womb of the sky-goddess Nut. So Augustus was considered as Horus, the son of god Re, and the Pharaoh of Egypt. ${ }^{39}$

The Imperial cult of Augustus was generally established in the Roman world, and in Egypt in special, depending on these three legendary stories disseminated by Sueton, Dio Cassius and the Egyptian Asklepiades of Meneds.

- He was proclaimed in Rome as the son of Apollo ${ }^{40}$

- He was known in the Roman world as "the New Alexander", and connected with the Greek Pantheon as "ZeusEleutherios"

- The Egyptian priest of Mendes, Asklepiades's interpretation that Augustus is “the new Egyptian Pharaoh". ${ }^{41}$

At first, Augustus in Rome made no claim or sought for a kind of divinity as a living man, and he refused to put his statues inside the temples, and took the ancient Republican title princes rather than king, probably he hoped to be deified after death as the model of Caesar. He knew that the Romans; especially the Senators, still yearned for the republic, and they still followed the Republican traditions, which still forbid a divine Emperor's cult as a complete god. His religious role is mentioned once in his "Res Gestae"; and he maintained the Roman tradition forbidding public worship of private men. This is well-attested by his frequent rejection of temples, cults and rituals, and his melting down of statues. $^{42}$

Later, step by step, his religious policy completely changed; he closely moved to veneration while living, he denied his father's modest rank, and recited the legends that he is the real son of Apollo. The court poets, introduced him to the whole world as a god. ${ }^{43}$ Only when he died, the Senate formally enrolled Augustus as god in the state cult, with Livia as his priestess. ${ }^{44}$

The Romans attitude towards Egypt was totally differ from that of the Ptolemies. The Romans considered Egypt as a seized country, the Emperor's duty was to keep the land of Egypt peaceful and prosperous for the Romans, depended heavily on the wheat and other products exported to Rome in vast quantities, as well as the substantial taxes extracted annually from the rich land. ${ }^{45}$

Except for the necessary conciliatory gestures towards the priesthood, Egypt was the monarchy of the Romans, and their emperors considered themselves the legitimate successors of the pharaohs. When Augustus inaugurated the tradition of embellishing Rome with obelisks he was not paying tribute to Alexandrian tradition and ingenuity, but celebrating a victory by bringing home spoils of war. ${ }^{46}$

The Egyptian sources refer that during the high priest of Ptah at Memphis called "Imouthes- Petubastis III" and his wife "Tneferos" (the musician of Ptah) has died two days before the arrival of Augustus to Egypt. ${ }^{47}$ He was mummified, but not buried, for seven years the mummified high priest took up a shelf-room in Per-nefer, the House of Embalming, and finally on 14 Pharmouthi, the $7^{\text {th }}$ year of the rule of Augustus (9 April 23 B.C), he was buried on the emperor's instructions. ${ }^{48}$ His successor was not immediately appointed. Two and a half years later, another high priest was appointed, he is called "Psenamun=Psenamousis II", he was installed in the $3^{\text {rd }}$ year of Augustus, 28/ 27 B.C. he was the cousin of his predecessor. ${ }^{49}$

The new priest had the title "prophet of Caesar" and was thus responsible for the cult of Augustus in Memphis. For the award of the title; he received a golden crown and many gifts for his new services for Augustus, and construction of a chapel was also authorized, which emphasis the good relationship between the priests of Ptah and Augustus. ${ }^{50}$

The "Prophet of Caesar" was following the Ptolemaic precedent of "the prophet of Pharaoh", Augustus by appointing this priest, with his new aspects, was allowing the personal aspects of his rule to be emphasized in Egypt, as a divine pharaoh enjoying the traditional support of the high priest of Ptah. ${ }^{51}$ 
The Egyptian priests prepared Augustus as a ruler in the first year of his reign in Egypt. So his name was inscribed in cartouche on the Gallius's stela ${ }^{52}$. Though the name of Augustus is inscribed in a cartouche as Kaisaros (son of Caesar) in the hieroglyphic text, and as Romaios (the Roman) in the lunette of the stela. ${ }^{53}$ The title pr-c3 (Pharaoh) did not appear in a cartouche for Augustus ${ }^{54}$.

Generally, Egypt differed from Rome and all Roman provinces. According to the ancient Egyptian traditions, the ruler was honored as a god. Therefore, Augustus, could not refuse the honor and prayers offered to him. To inherit the honor and power of the pharaoh, he had to be the divine ruler. He had his statues erected in all the Egyptian temples over the years, and became asylums in Egypt. ${ }^{55}$

Augustus received the only three ancient Pharaonic titles; the Horus, the Nsw-bity and the S3 R' names. The word Kysrs (Caesar) was part of his son of Re's name, which emphasized that he did not receive his authority and ability from the Egyptian gods, but from the imperium granted to him by the Senate and the Romans. In his first years of reign; the Egyptian word hrmys (the Roman) was part of his Nsw-bity title. However, in the $9^{\text {th }}$ year, it was replaced by the word Awtkrtr (Autokrator), ${ }^{56}$ which was the official name of the emperor Augustus. ${ }^{57}$

The Horus name of Augustus emphasizes the good relation with god Ptah. ${ }^{58}$ It contained elements of Egyptian royal ideology, praising the ruler as an ideal Egyptian Pharaoh. Augustus was portrayed by this name as the mighty ruler in Rome, who captured Egypt, protected it from the enemies, ensured law and order, looked for the prosperity of the Egyptians, and maintained a good relationship with the Egyptian gods. The Horus name also includes components of the royal titular of the Ptolemaic period. The name referred that Augustus's residence in Rome, not in Egypt, and his domain and justice distributed in the whole population. ${ }^{59}$

In order to prevent turmoil, Augustus preserved the rights of the priests and the temples left unchanged, as a first political step, but he exercised strict control over their income and movements; this resulted finally in the appointing of "a high priest of Alexandria and of all Egypt", ${ }^{60}$ with the assistance of local high priests in the nomes. The chief high priest of Alexandria and all Egypt was mainly a Roman civil official "exegetes", which was known from the Ptolemaic period, who had not exactly a religious function but served as a sort of minister of religious affairs. ${ }^{61}$ The office of the high priest of Egypt in Alexandria included direct concern for the imperial cult, his the full title as "high priest of the lords Augusti and the Great Serapis, and the one who was responsible for the temples of Egypt and the whole country".

Since Augustus the Praefectus Aegypti involved in the administrative affairs of the temples, in the $1^{\text {st }}$ century A.D, he prescribed his Idios Logos for the administrative of the temples' affaires. ${ }^{62}$ The high priest of Alexandria functioned not only as a high priest of all the Egyptian temples and their gods, but as a bureaucrat, supervising the temples' affaires, has to control access to the Egyptian priesthood, all under the control of the Roman government in Egypt, responsible for the administrative oversight of all cult activities in Egypt, controller for the priests actions, activities and incomes, with careful reports and supervision acted as a mediator between the public and the Egyptian temples, he was responsible for the registration of all temple personnel, their families and property, and solving the problems and abuses of the Egyptian temples, in addition to his cultic responsibilities. ${ }^{63}$

The imperial cult was official, but it was not, as under the Ptolemies, organized by the central regime, but municipally, by the magistrates of the Greek cities and nome capitals. ${ }^{64}$ Most likely, there was a high priest who assisted in a provincial capacity as a subordinate of the high priest of Alexandria, given the local nature of most Egyptian temples; he was identified merely as "high priest of the gods Augusti. ${ }^{65} \mathrm{He}$ was of a Roman origin, may be was fullfledged member of the archontes, who serving as a ruling council, and they had a real authority to the metropolis. ${ }^{66}$

Augustus failed by his imperial cult to meet the approval of the Egyptians as Alexander the Great or the Ptolemies had met. The Roman emperors has no great cult in Egypt or great festivals as the Ptolemies in Alexandria. The imperial cult in Egypt didn't touch the public hearts, possibly was approved only by the beneficiaries, or the high classes of the society between the Greeks and the Hellenized Egyptians. No reference for the connection between the Imperial cult of Augustus in Egypt and goddess Rome, as in other Roman provinces. Pfeiffer suggested this due to the special rank of Egypt and the absence of the Senate's power and role in Egypt, that the worship of goddess Roma was closely connected with the Senate, which is why Augustus did not introduce it in Egypt. ${ }^{67}$

He had the Greek title Basileus, which was used also by the Egyptians in the Ptolemaic Egypt. He was especially identified with Zeus in his formulas, as Zeus Eleutherios Sebastos. This title was used for private worship, and was found also in temples. This special role of Zeus seems to have excluded the worship of goddess Roma with Augustus in Egypt, which was sponsored by Augustus in other Eastern provinces. ${ }^{68}$

The religious reforms and fluctuations was among the most personal works of Augustus; and it was long in an experimental stage as Augustus sought to misuse religion in achieving various functions, though still respect the gods. He denied Antony's sought for divinity, with the help of Cleopatra, Augustus recognized. Adjusting religious policy was still a new technique and approach in Rome. Augustus built his own new prestige either by establishing a religious policy differs in Rome from that in Egypt and the Hellenistic East, or by discrediting Antony's claims to divinity. 
Augustus appeared in Egyptian temple reliefs as a complete Pharaoh, bearing his extensive titular and epithets. He either acting his role towards the Egyptian deities. In addition to his special divinity inside these temples; he has a true cult associated with these deities and was celebrated in accordance to Egyptian rituals inside the gods' temples. ${ }^{69}$

\section{The main centers of the imperial cult}

The precise beliefs and practical details of Roman imperial cult for the Emperor is a subject of debate between scholars. The Imperial cult required the presence of a "ruler" king, emperor or otherwise, and the Roman republic in the very nature of this term had no ruler, ${ }^{70}$ whether the Romans actually considered the living Emperor as a true god or not, during the time of Augustus, a large number of temples throughout the empire were built containing statues for the Emperor, in addition, festivals and sacrifices were carried out on his honor. ${ }^{71}$

\section{The Caesareum of Alexandria}

Augustus initiated his imperial cult in Egypt inside the Caesareum ${ }^{72}$ (Sebasteion), ${ }^{73}$ which begun by Cleopatra for Antony. This was subsequently rededicated to Augustus, who changed it for his own cult and complete its building, ${ }^{74}$ and referred to as the "temple" or "shrine" (Caesaris templum, or Caesareum Magnum). ${ }^{75}$ Whilst there is agreement that later, it was a cult center for the worship of the emperor Augustus, there is uncertainty about whether its construction was in honor of Julius Caesar or Mark Antony by Cleopatra. ${ }^{76}$

The central Roman authority for founding a cult for Augustus was at work in Alexandria. However, the cult was supported by the citizens in Alexandria, whose the neokoroi- the cult officials designated as "temple guardians"-from among their ranks. ${ }^{77}$ The Caesareum was not only a temple but was enlarged as a complex-building on elevated location to be visible to all to the right side Alexandria harbor. Two obelisks were erected before, now, they are in London and New York. ${ }^{78}$ One of them bore the dedicatory inscription "Year 18 (13/ 12 B.C) of Caesar. Another obelisk was demonstrated by Alföldi, now in St. Peter's Square in Rome, also belonged to the temple of Augustus at Alexandria. A Latin inscription on its base reads as:

"By order of the emperor Caesar, son of God, Caius Cornelius Gallus, son of Gnaeus, the Praefectus Farbrum, constructed the forum Iulium ${ }^{79}$ for Caesar, the son of the god"

The Complex buildings of the Caesareum based on a model from the city of Rome or a Romanizing model as an official buildings of the city of Rome. Since a Roman administrator in his office at Alexandria was appointed for the service of this new cult and involved in erecting obelisks at the complex and supervising the project buildings. A letter from the emperor Claudius to the Alexandrians set out a lottery process for electing these cult officials in the Caesareum, which eliminated the influences of certain parties of the Alexandrians on the election process, this emphasis the connection between the Caesareum and the Imperial cult. ${ }^{80}$

A Roman official named "Pontius" was responsible for the completion of the imperial cult complex. ${ }^{81}$ The Kaisareion at Alexandria certainly remained an active temple of the imperial cult for more than two centuries. ${ }^{82}$ The temple remained an object of cult for sailors, ${ }^{83}$ and merchants of grainswho are coming to Egypt as the principal suppliers of grain, dues to Augustus's victory, ${ }^{84}$ given the significance of the grain shipments for both sides. An inscription found among the debris of what was probably the Kaisareion appears to be a dedication by the "dekanoi" of a Classis praetorian in honor of "Theos Kaisareion", providing strong evidence for the inclusion of successive emperors in the temple as "Synnaoi". Several high priests names were known during the reign of Marcus Aurelius and Septimus Severius. ${ }^{85}$

By 94AD, the enclosure included subsidiary shrines and was also used as a public place for displaying notices, as a solider report a bronze copy of his certificate of discharge was "lodged in the Great Caesareum, as you mount the second stairs, within the right-hand portico, near the temple of the Marble Venus, fastened on the wall". ${ }^{86}$

The cult was created in the Greek cities to understand the emperors' power in their lives, and the primary impact of the new ruler on the Egyptians was the grain tribute. The Kaisareion was converted into a Christian church in 313 A.D, or perhaps a church was built within the temenos. This was destroyed in 912 A.D. ${ }^{87}$

\section{The Augustan's temple at Phila}

Augustus erected a temple at Phila, ${ }^{88}$ his dedication is inscribed upon the architrave of the temple as "For the emperor Caesar Augustus, savior and benefactor, in the $18^{\text {th }}$ year (13/12 B.C), during the term of the office of (the praefectus Aegypti) Publius Rubrius Barbarus". ${ }^{89}$

Another inscription composed of three fragments, these had been used as building material for the later Coptic dwellings nearby (pl.1), comprise the titles of Augustus as Soter and Euergetes. Probably, his victory over the Nubians and his successful defense of Phila against the incursions of Nubians, makes him as Soter and Euergetes, it was more than adequate motivation for dedicating the temple..$^{90}$

The temple was built in the same year of completing the enlargement of the Caesareum of Alexandria. This was either the same year in which Rubrius dedicated the obelisks before the temple in Alexandria. ${ }^{91}$ It is a Roman podium temple, measured $18 \mathrm{~m}$. by $10 \mathrm{~m}$., it carries a mix between Egyptian and Roman design and elements, a mixed Doric- 
Corinthian temple. The temple is semi-damaged, without inscriptions, in the open space in front of the sanctuary, the foundation of a sacrificial altar can be detected, and a staircase can also be seen (pl.2). ${ }^{92}$

\section{Chapel at Karnak}

This is a small chapel, of $8.6 / 14 \mathrm{~m}$, lies next to the causeway of the temple of Amun, to the right before the first pylon. It is built of stones and mud-brick, it is distinctly Roman in appearance, and it bears comparison with other Emperor shrines throughout the empire. ${ }^{93}$ The temple was built in Karnak to associate the imperial cult of Augustus with Amon. It is proto in design with an arrangement of four by two columns; which were of Corinthian design, since a column capital of that type was found. This can be attributed to the building, remains of a granite staircase leads to the chapel's entrance as a podium-chapel (pl.3). ${ }^{94}$ The granite staircase leads to the small pronaos, followed by a naos almost twice the size of the pronaos, the naos supposed to hold the cult-statue of the Emperor. ${ }^{95}$ Pfeiffer suggested that the temple most probably dedicated to Augustus for many points:

- Fourteen emperors' statues were found in the cella of the chapel, two of them belong to Augustus, and three to Claudius. The others are not inscribed.

- The similarity with its larger chapel of Phila.

- The similarity with a Dalmatia at Natrona, a free-standing imperial cult-chapel with similar features. Around it sixteen imperials' statues dated back to to the time of Trajan, exactly the $1^{\text {st }}$ century. ${ }^{96}$

- The two statues of Augustus bear dedications to him as "son of god, Zeus Eleutherios". This divine affiliation appears only in Greek and Demotic documents, and the present reference of Augustus as Zeus-Amon referring to the existence of the statue in the precinct of the temple of Amon at Karnak. While the epithet Zeus Eleutherios is not attested until the $7^{\text {th }}$ year of Augustus (23 B.C), suggesting this shrine was not built until the political situation had stabilized in Upper Egypt and Nubia. An uninscribed colossal royal statue found at Karnak, now in the Egyptian Museum (CG 701), has been identified with Augustus as an Egyptian Pharaoh, although the exact provenance of the statue is unknown. It may have been placed within or before the Emperor's shrine. Another colossal statue for Amenhotep son of Hapu was found in the immediate vicinity, ${ }^{97}$ with the Greek titular of Augustus inscribed as "Kaisaros Autokrator, son of God, Zeus Eleutherios Sebastos". Klotz assumed this statue was engaged in the Imperial architectural ensemble in front of the first pylon of Karnak. In addition to the reference to Amenhotep son of Hapu receiving Snw-offerings from the altar of Amun, this may hint a similar cult practices rendered to the adjacent statues of Augustus and his descendants, which were found in the chapel. ${ }^{98}$

- The imperial cult shrine at Karnak has dual functions; as a functional Egyptian temple and containing statues of the ruling emperors ${ }^{99}$.The chapel was built over an earlier Ptolemaic structure, within it were found the statues of Ptolemy VI and Cleopatra II, which emphasize that these various Roman cult- statues were worshipped inside the shrine for the Emperors as these Ptolemaic cult statues. ${ }^{100}$

The similar structure and layout of the Karnak chapel and this of Phila, suggested the same construction date; to be the $18^{\text {th }}$ year of Augustus reign, precisely (14/13 B.C). ${ }^{101}$ Although there are earlier references of the imperial cult at Phila before this date; the Gallius's stela (26/ 25 B.C) mentioned the Meriotic armies invaded Upper Egypt, defeated the three cohorts stationed in Syene, captured Elephantine and Phila, and "pulled down the statues of Caesar. ${ }^{102}$ This refers to a cult of Augustus existed in Phila before the official construction of this shrine in the $18^{\text {th }}$ year, and the bronze head of Augustus found in Meroe may had belonged to such a statue. ${ }^{103}$

The bases of Augustus' two statues from Karnak, as well as the colossal statue of Amenhotep son of Hapu, both described Augustus as "Zeus Eleutherios", he was not refereed to him as theos (god) may indicate the statues were dedicated during his lifetime. ${ }^{104}$

Augustus was interested in building temples and chapels with Corinthian- columns. ${ }^{105}$ Many other temples were built in Egypt for the worship of the Roman emperors "Kaisareia or Sebasteia", were situated in the Chora of Egypt, some of them dated back to the reign of Augustus, and others were built later. The existence of "Ksiareiaor Sebasteia" can be proved for Philadelphia, Heptakomia, Arsinoe, Antinoopolis, Herakleopolis, Oxyrhynchus, Elephantine, and probably Lykopolis. ${ }^{106}$ The Kaisareia were existed in the nome capitals, there is evidence from the villages of Philadephia and Heptakomia. ${ }^{107}$

\section{- Augustus, Cleopatra and Ceasreion}

The conquest of Egypt and the defeat of Cleopatra were clearly fundamental to the stories, which the Romans narrated about the origin of August's power. As a symptom of the Augustan's prevalent anti-Egyptian feeling, it is worth remembering that the scandal caused by Antonius and Cesar's relations with Cleopatra had a racial rather than a moral background. ${ }^{108}$

Cleopatra's arrival in Rome was early in August 46 B.C, she had hardly reached Rome in less than 50 days. ${ }^{109}$ She accompanied Caesareion on her journey to Rome, where his father would see him for the first time. Caesar ordered a gold image of Cleopatra to be placed in the temple of Venus Genetrix. ${ }^{110}$

Cleopatra was not only a queen in her own right, however, in her country she was as a goddess as all her ancestors, and accompanied the gods in their sanctuaries. To the Romans, however, such an act as placing a gold image 
of a foreign queen beside the cult image of Venus in her Roman temple might have seemed extraordinary and unusual. H. Volkmann assumed "this was more" than an act of a man's action towards his beloved woman; it was very plausibly a decree which has its political and religious aspects and visions. ${ }^{111}$ It was an excessive personal honor to Cleopatra, but it does not entail, in the eyes of the Romans, as a kind of deification or a step towards deification. ${ }^{112}$

The assassination of Julius Caesar placed Cleopatra in an untenable position; she could not approach Octavian because his character was so vehemently antithetical to hers. The contemporary sources describe her not as a renowned beauty, but as a woman of extraordinary personality, besides being very attractive. ${ }^{113}$

The Romans denied the attitude of Antony towards Cleopatra, that he will transfer the Roman capital from Rome to Cleopatra. Moreover, he will offer the Romans' territories as gifts for Cleopatra and their children. Antony had his picture painted together with Cleopatra, as a personification of Osiris and Isis. These Antonys' actions give the Romans a serious conclusion about how he was carrying on. Antony allowed Cleopatra to conduct public business with him and rode with him in cities, or at other times he walked behind Cleopatra's carriage. ${ }^{114}$ Her attempt to identify herself as Isis continued during her relationship with Antony. She dressed as Isis, probably in black during the celebration feast in Alexandria for Antony's victory over the king of Armenia in 34 B.C. This celebration, which was known as "the ceremony of the Donations", where Antony offered gifts to various territories for Cleopatra's children. This was the first time to celebrate such event outside Rome, later many Romans became angry of. ${ }^{115}$

Augustus himself refused this action, he deprecated and irked due to the words that claimed Caesareion as the true son and heir of Caesar, Suetonious referred "declared to the Senate that Caesar had really acknowledged the boy, and that C. Matius, C. Oppius and other friends of Caesar knew this". ${ }^{116}$ Augustus denied that Caesareion was the true son of the dictator and had stronger claim than to be his heir. ${ }^{117} \mathrm{He}$ did his utmost to suppress -at any cost -the report of Caesar's paternity of the boy, regardless of whether it was true or false. After Actium, he hesitated in getting rid of him at once. Consulting what was best to be done with Caesareion, when Cleopatra was dead (c. 12 Aug. 30), Caesareion was killed when he was about 17 years old. Augustus could not very well enthusiastic and ready to accompany an authentic or spurious son of Caesar to Rome to grace his triumphal procession. ${ }^{118}$ Since Cesar's paternity of Caesareion was suspect and perhaps hotly debated in Rome and Caesar himself took no tangible step towards acknowledging the child. $^{119}$

The naval battle of Actium in September of 31 B.C was of momentous importance for the history of the West because it placed the last two independent states of the Mediterranean world against one another. Cleopatra VII and Antony represented the culture of the Ptolemaic Egypt, while Octavian represented the Roman. The battle is the revenge of the Western world against Cleopatra and Antony. 20

Augustus, as Caesar's grand-nephew was appointed as heir in his will to most of his property, not to his dominant authority or absolute power or his hegemony. In 45 B.C, after Caesar's return with Octavian from Spain, Caesar's main concern, being childless, Octavian whom he regarded as the most promising of his younger $-18^{\text {th }}$ years old- kinsmen. He could not imagined this teenager would succeed his own sovereign power, or would eventually emerge as master of the Roman world. ${ }^{121}$

Cleopatra was the enemy of Augustus; his celebrations at Rome after Actium dues to his triumph over Cleopatra and seizing Egypt. An image of the dead Cleopatra on her couch was paraded through the city in the absence of her living itself, together with Alexander Helios and Cleopatra Selene, her twin children by Antony. Immediately, after Actium battle, Augustus made several triumphs over Cleopatra after the conquest of Egypt. He was perhaps rather relieved by Cleopatra's timely suicide, which meant he did not have to drag her in chains through the streets of Rome in his triumphal procession. ${ }^{122}$

The Portrait of Cleopatra and Egypt in the Augustan poetry has two essential sides; the first is more well-known and popular, is that which presents Cleopatra as a hedonist, over-sexed woman or a notorious prostitute. This aspect carries a shameful reputation for an Egyptian queen by the Roman writers. The second side, represents Cleopatra as ambitious queen, her deeply hope to keep the Egyptian throne safe against the Roman dangers, but also to widen its territories. $^{123}$

Later, this Augustus's vindictive attitude towards Cleopatra and Caesareion was turned, Augustus depicted himself as the father of Caesarion in a stela, which depicted himself as a pharaoh making offerings before the crocodile - god, Suchos of Fayoum. The stela was mainly dedicated for Cleopatra by Augustus. ${ }^{124}$ It was found in Arsinoe/ Krokodilopolis, the capital of the nome Arsinoite in Fayoum. The inscription can be read as:

"For the queen Cleopatra, the goddess who loves her deified father (Philopator), and for the king Ptolemaios, who is also a Cesar, the beloved by his deified father and mother= TheaPhilopator ${ }^{125}$ (Philopator and Philometor), and by the ancestors, to Suchos, the Great God, the Great, the father of their father, Artemidoros".

The stela is dedicated for Cleopatra and her son Cesareion between 44-30 B.C. It is divided into three sections; the winged solar disc with two uraei in the upper most part. The middle part depicts a pharaoh, while making offerings before the crocodile-god Suchos, as a human-body with a crocodile-head, holding the Ankh-sign in his right hand, and a scepter in his left hand, and a naos with a bust- figure of a pharaoh with nemes-headdress lies in between. However, the third register contains a Greek inscription in four lines (pl.4). 
Augustus acted on the tradition of the Ptolemaic dynasty of worshipping the sovereigns in the royal Ptolemaic dynasty. He wanted to save the ancient Ptolemaic traditions of the ancestors' worship, as the Ptolemaic royal family cult. Caesar and Antony were partners of Cleopatra and fathers of her children, so he wants to act as the savior and benefactor of Cleopatra and her son Caesareion as the father of her deified child. ${ }^{126}$ Therefore, he considered himself as "the heir of Cesarieon" in Egypt, and has the title hk3 hk3w "king of the kings". ${ }^{127}$ Augustus was interested in adding and completing Cleopatra monuments, the Augustan reliefs of Luxor temple lasted earlier decorations from the reign of Cleopatra VII and Cesareion. ${ }^{128}$

Cleopatra was named by the inscription as "Thea Philapator", while Caesareion is named as Cesar, the beloved of Philopator and Philometor as a traditional Ptolemaic title for the son to be the beloved of his father and mother. So Augustus was the legitimate heir of the Ptolemaic Egypt and the Ptolemies, who considered themselves the heirs of the Pharaohs, and according to the ancient royal Ptolemaic traditions. Augustus has to raise the ancestors (Cleopatra and Cesareion) to god's level. Especially, the divinity of himself as a god after his conquest of Egypt was one of his major aims. So he depicted himself -like the Ptolemies- as a pharaoh on the Egyptian temples, offers and sacrifices for the Egyptian deities, and he looked forward for establishing his new imperial cult in and outside Egypt. Here Julius Cesar's intention was to represent himself as the father of the child Caesareion, whose father was Roman Cesar, and the child was either named in the inscription as Cesar, ${ }^{129}$ especially Augustus paid a great attention to Caesareion. ${ }^{130}$

In Egypt Cleopatra was regarded not only a Queen, but either a divine goddess according to the ancient Ptolemaic traditions of the ancestors' divinity. She assimilated with Goddess Isis and appeared in her guise. Astela was found in Fayoum within the temple of Soknopaious- Nesos at Dimeh attributed to Cleopatra VII. ${ }^{131}$ The upper part of the stela shows a seated goddess nursing her child, may be Isis. A pharaoh wearing the pschent, presents two globular vases for the goddess (pl.5). The Greek inscriptions of the lower part have been deeply engraved, except for the last lines, and bears traces of red paint. According to the dedication formula, this stela was consecrated by the chief of the association of the devotees of the goddess Isis "Sononais", who was also the administrator of her temple in Fayoum. The stela described Cleopatra also as Thea Philopator, the beloved of her father, which attributed the stela to Cleopatra VII during the $1^{\text {st }}$ year of Epiphi reign (2 July 51 B.C). ${ }^{132}$ The Greek texts below translated as follow:

"For Queen Cleopatra, the goddess, the father-loving (has been dedicated) the seat (topos) of the association (of Isis-Snonais, the president of which is Onnophris. July 2, 51 B.C". ${ }^{133}$

The stela is therefore believed to have been re-carved after Cleopatra's sole leadership. It appears the present inscription was recut over an earliest text. The letters are both diminished and crowded together in lines 7-8. The inscription is sunk lower into the background than the scene on the upper part of the stela. It is thought the scene originally depicted Ptolemy XII, whose name would have been engraved before its modification. Especially, there is another similar stela attributed to Ptolemy Auletes, it either depicts him making offering before Isis of Chemis in Fayoum(Pl. 6). ${ }^{134}$

The inscription was probably by Auletes (80-58 B.C), and then was usurped and re-written later during the reign of Caeasr.Though the stela was found in the Cleopatra's Isis temple in Fayoum, which dated back to her reign. However, Sally Ann-Ashton excluded that the Egyptian pharaoh is the queen Cleopatra. ${ }^{135}$ She is depicted as a malepharaoh adores goddess Isis. The obligation for this idea is due to the scarcity of the queen's representation as a male king. ${ }^{136}$ While the shift between the preparation grid and the lines of the inscription have been regarded as proofs of this deliberate alteration. However, this shift perhaps was made by the engraver concerning the inscription's size, so he had to cut the frame's lower part to add an extra line. ${ }^{137}$

The character of the Pharaonic figure in the stela may indicated the queen herself. This probably had related to her Ptolemaic father Auletes, or may be related to King Ptolemy XIII, Cleopatra's partner in reign. In addition, her husband is making homage for Isis, or to his wife Cleopatra. The New Isis, as King Ptolemy II was done with his wife Arsinoe II. In this stela, Cleopatra assimilates with goddess Isis, who is suckling her son Harpocrates as "New Isis", ${ }^{138}$ especially in another relief stela. Cleopatra was also assimilated with goddess Mut, and her husband Julius Cesar as Amon, while his son as the child Chonsu, the triad of Thebes (Pl. 7). ${ }^{139}$

So Augustus has to change his attitude against Cleopatra from enemy during her life to one of the deified predecessor and her subsequent heir upon the throne of Egypt after her death. So Augustus conducted and completed earlier Cleopatra's constructions; among the numerous scattered temple blocks found at the Graeco- Roman temple of Tod. Several have been recently identified to belong to Augustus, just as Armant, Medamud, and Khonsu temple. The Augustan reliefs continue earlier decoration from the reign of Cleopatra VII and Caesareion. ${ }^{140}$

\section{- Augustus and the Apis bull}

Generally, it was well-appeared that Augustus harbored great antipathy toward the eastern cults, and the Egyptian cults in special. It is frequently claimed that he was appalled and disgusted by Egyptian religiosity, which centered on the worship of common animals. Many Romans and Greeks found the idea of worshipping animal was strange and even ridiculous. This attitude became stronger by the propaganda campaign of Augustus against Cleopatra, which was described by some of the Roman writers as "a religious war" against Egyptians and their beliefs. Augustus himself was 
the author of much of the propaganda against Cleopatra and Antony, and their supported gods. This was emphasized by Dio Cassius speech: ${ }^{141}$

"Would we not to be behaving quite shamefully, if, having exceeded all men in valor, we should meekly bear the insults of these, who are. O Hercules! Alexandrians and Egyptians (and what worse or truer name might apply to them?), who worship reptiles and other beasts as gods, who embalm their bodies for a semblance of immortality, and. who are slaves to a woman and not to a man?"

Though Augustus the founder of the Roman imperial didn't make as his pacemaker, Alexander the great, ${ }^{142}$ who venerating and making offering for the Apis bull, ${ }^{143}$ Augustus declined the veneration of the Apis bull. He refused to make offerings to Apis, deducing he would make offerings to gods, but not to beasts or bulls. ${ }^{144}$ Augustus refused to carry out one of the most intrinsic duties of an Egyptian king. ${ }^{145}$ Egypt's animal deities could present a shocking prospect for Romans used to anthropomorphic gods. ${ }^{16}$ Therefore, during the age of Augustus, worshipping animals was refused by the Roman in their poems. Dio Cassius in his description of Egypt referred to Apis as: ${ }^{147}$

"It rained not only water where no drop of rain had fallen before, but also blood; and there were flashes of armour from the clouds as this bloody rain fell from them. Elsewhere there was the clashing of drums and cymbals and the notes of flute and trumpet, and a serpent of huge size suddenly appeared to them and hissed with incredible vehemence. Meanwhile comets were seen and dead men's ghosts appeared, the statues scowled and the Apis bellowed a note of lamentation and burst into tears".

The Roman poet "Tibullus" (55-19 B.C) introduced the Apis-bull in his poem in honor of Messala, refer to the customs of the Egyptians' mourning on the death of the Apis bull. ${ }^{148} \mathrm{He}$ described that worshipping animals here does not serve as an illustration of a silly cult but also as a wondrous phenomenon from a strange and far-way country. ${ }^{149}$ Therefore, Augustus may, in fact, have shared the Roman aversion and disagree of worshipping animals, although that is not the most likely motivation in such a political situation, that Grenier described Augustus' action as "disagreeable" and compared with the atrocities attributed to the earlier Persian conqueror, Cambyse had done, that he described him as the "New Cambyse". 150

The contradictory feeling of Augustus towards the Egyptian animal cults, especially the bulls, was appeared on two stelae, ${ }^{151}$ which are portraying the Roman emperor under the homage and veneration of the Buchis bull of "Hermonthis"(Armant) (pls.8, 9), in his attitude as a pharaoh. ${ }^{152}$ One of these steles gives a date of "year 1, Pharmuthi 21 of Cesar" a mere five or six months since the beginning of Augustus's rule (29 B.C). ${ }^{153}$ This bull was born perhaps under Ptolemy Auletes (53B.C), then was perhaps installed under Cleopatra VII (51 B.C), and have died under Augustus (29 B.C). The cartouches of Auletes and Cleopatra VII are empty. Augustus is depicted making offerings to the god, who stands on top of a pedestal with an offering table.

Fairman suggested, Augustus does not bear the developed titular which the Romans eventually assumed. Therefore, he assumed the stela was set up when the claims of the emperor to be a legitimate Pharaoh had not been recognized, a period of transition, when a mere private person might venture to usurp the royal prerogative. Augustus was either described in the inscriptions as: "the mighty one, beloved of the Osiris Buchis, Great God, and Lord of the House of Atum". ${ }^{154}$

Wilcken suggested Hermonthis played a role during the struggle between the C. Gallus and the Nubians in 29 B.C, and that the priests of Hermonthis, as a kind of their defeat, ${ }^{155}$ and their refuse of the Roman rule. They used "the kratesis, or the Roman date", instead of the usual "royal" date, ${ }^{156}$ to avoid recognizing Augustus as a legitimate king by using a cartouche. ${ }^{157}$ As a result, Augustus did not forbid the animal cult in contrast of the earlier Roman and Latin sources of his reign.

Later, Augustus titles were associated with Ptah and Apis, who was considered the soul of the creator- god Ptah, ${ }^{158}$ whom Augustus has a close relation with, and his Horus-name was mainly addressed to Ptah. The Apis bull was living in the area and under the supervision of the great temple of Ptah at Memphis, shared in his festivals, and the high priest of Ptah was responsible for the cult of Apis. His serve for the cult of Apis was among his religious titles. ${ }^{159}$ Augustus was called asStp. N PthNww it ntr.w "chosen by Ptah-Nun, the father of the gods", also he was also entitled

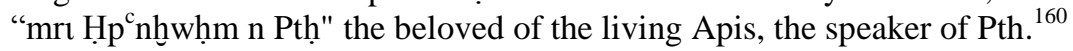

Later the Roman emperors gave great attention to the Apis and the Buchis bulls, Vespasian-most probablyportrayed sacrificing before the Apis bull at Kom el-Schukafa. ${ }^{161}$ Titus visited Alexandria, on his way, he sanctified to Apis bull at Memphis in 70 A.D. ${ }^{162}$ Hadrian depicted himself with the head of Apis on his coins, ${ }^{163}$ and Diocletian has a stela depicts him in the honor of the Buchis bull, this dated back to 288 A.D. ${ }^{164}$

\section{- Augustus and Isis}

During Augustus's war, the literary poets of the Romans were equivocal in their attitude towards Egypt's religion, always mocking on the worship of the animal gods. They were also suspicious of the Isis priests and their followers in Rome. The priests were accused of mendacity and the temples of Isis were regarded as places of lewdness. ${ }^{165}$ Her followers were mainly girl-friends as mistresses and sexual matters, and they sometimes invoked Isis in their poems. ${ }^{166}$ 
In October 43 B.C, in a marked reversal of policy following Cesar's assassination, the second Triumvirate decreed the construction of a temple to Isis and her consort. ${ }^{167}$ The worship of Isis and Serapis was officially organized, a huge promotion of the cult of Isis began. When the Triumvirs-Antony, Octavian and Marcus Lapidus agreed to restore order to the state in the aftermath of Cesar's assassination and subsequently vowed to erect a new Iseum at Rome, ${ }^{168}$ known as "Campense", ${ }^{169}$ in the Campus Martius, outside of the Pomerium (the official sacred boundaries of Rome). ${ }^{170}$ The decree sought to the support of the "populares" in his struggle against Antony at the time, and to put a political need for an authorization of the Isiac cult in Rome. Evidently to court their favor, to have the cult of Isis and her followers, and adherents fit into the late Republican system. The plan, however, was never carried out.

During the Republican Rome, the persecution of the cult of Isis was undertaken by Augustus; though originally lenient to the worship of Isis along with other foreign gods. He considered his former brother in-law Mark Antony, now enemy and dangerous to Rome and to her gods. ${ }^{171}$ Octavian was not welcomed by the Egyptian divinities (Serapis, Isis, Harpocrates and Anubis) in Rome. ${ }^{172} \mathrm{He}$ was typically described as apathetic or even hostile towards local Egyptian traditions and Egyptian cults in Rome. This perception is the result of the formal propaganda directed against Antony and Cleopatra, and general ant-Eastern sentiment prevalent in Rome before Actium. ${ }^{173}$

Augustus had aggressive attitude towards these divinities, especially its animals' figures. He refused to render homage to the bull Apis and execrated the doglike form of Anubis who became bitterer with Augustus, though he paid homage to Serapis in Alexandria, ${ }^{174}$ as a Greek- Alexandrian's god. ${ }^{175}$ In 30 B.C, a decree called for the temple destruction, but no workmen could be found to do this, until the consul himself took up the axe. ${ }^{176}$ The close connection between Cleopatra and Isis increased the hate and the hostility of Augustus towards Isis. Cleopatra was worshipped as Isis. $^{177}$

Under Augustus, the emperor (30-14 B.C), the more powerful he became, the more openly he showed his animosity towards the Egyptian cults. In 28 B.C, Augustus refused to have Egyptian shrines within pomerium, ${ }^{178}$ and prohibited the celebration of the Egyptian rites there, ${ }^{179}$ especially for the cult of Isis, instead of building a temple there, as he once promised. ${ }^{180}$ However, he permitted her cult elsewhere outside the pomerium of Rome, because he was preparing his grand imperial cult that took place the following years later, and did not wish to alienate anyone.

During Augustus's life time, Isis worship was prohibited within the pomerium, but the Roman people appear to have paid little attention to this restriction. ${ }^{181} \mathrm{He}$ regulated the veneration of the deos Alexandrinos (gods of Alexandria), condemned animal worship and its degenerations but safeguarded the cult of Isis. The Augustus's ban of the Alexandrian's cult didn't include the worship of Isis and Serapis, ${ }^{182}$ though the Isiac cult continued secret in underground private chapels within the families, especially between women. ${ }^{183}$

In 21 B.C, troubles assailed Rome while Augustus was in Sicily. Agrippa, his son-in-law, restored order and drove the Egyptian cults from the pomoerium, which again invaded the city. ${ }^{184}$ In the same time, the Egyptian cults were even banned from the suburbs of Rome within a radius of seven and a half stadia (One mile, 1,330 km) in a bid to curtail the Egyptian rites. ${ }^{185}$ Agrippa's decree may have been carried out with the approval of Augustus or not! ${ }^{186}$

Later Dio Casius claimed that Augustus in the $10^{\text {th }}$ year B.C had erected two Egyptian obelisks taken from Heliopolis (one in the Campus Martius, and the other is in the Circus Maximus). He adorned his mausoleum with two uninscribed obelisks (the tomb itself have much Egyptian ornament). ${ }^{187}$ He had erected sanctuaries for the Alexandrian gods whom he had excluded before. ${ }^{188} \mathrm{He}$ appeared also on walls of the Egyptian temples in the homage of Isis. ${ }^{189}$ As a result, he built and either accomplished many structures attributed to Isis.

Augustus was not simply expressing his personal attitude and feelings towards the Egyptian gods, especially towards Isis, who later became his beloved goddess. He built the temples for her worship, and depicted himself in the full homage and worship of the Egyptian goddess, which suffered a lot under his reign, and prohibited in Rome according to his decrees. Augustus portrayed himself in a veneration- attitude before Isis upon the Egyptian temples, especially at Kalabscha and Phila.

Whether Augustus was interested in Egyptian cults or not; he was certainly aware of the propagandistic benefits of displaying his image and titular in temples of Egypt, Nubia, and other provinces. The imperial money spent restoring temples, and the Roman administrators, soldiers, and laborers sent to carry out these works, would all help to pacify the notoriously rebellious native Upper Egyptians against the Roman conquest. It is notably that most of Augustus's constructions in Egypt focused on the areas of revolutions and struggles; inside the Theban region and Lower Nubia. ${ }^{190}$

Augustus later, especially during the Imperial period, paid attention to the cult of Isis both in Egypt and Rome. He appeared with all the iconographical characteristics and comportment of a god-king, or Egyptian pharaoh building sanctuaries or adoring Isis. He probably became a victim of Isis.

\section{Kalabscha}

From the beginning of Roman rule, Octavian was depicted as a pharaoh, as exemplified by the Kalabscha gateway. ${ }^{191}$ The kalabscha temple was built in the late Ptolemaic period, and a gateway was added under Octavian, the temple was then rebuilt, but never been accomplished under Augustus. The gateway, now reconstructed in Berlin (pl.10), ${ }^{192}$ had been decorated under Octavian in the years 30-27 B.C. ${ }^{193}$ The archaeological evidence of the early Roman period, 
depicts Augustus and Tiberius on the walls of Kalabscha temple in the Pharaonic attire, that Augustus wasn't to present himself as the legitimate successor of the Ptolemies, and even of the Pharaohs. ${ }^{194}$ When the temple of Kalabscha was moved because of the constructing of the Aswan High Dam, the gate was discovered reused as building material in the Augustan temple.

The gate had been constructed and decorated before Octavian was even named Augustus in 27 A.D. ${ }^{195}$ He was depicted on the gate as a pharaoh, entitled as Kjjsrs p3 ntr (Caesar, the god). He is depicted once with the red crown of Lower Egypt, and another time with the double crown of Upper and Lower Egypt. The uraeus on his forehead, and the royal kilt of the pharaoh, is offering the shyt before Isis (pl.11), ${ }^{196}$ and appeared under the veneration and honor of Isis in many representations upon the temple (pl.12). Augustus is either depicted offering lotus flowers to Isis and Horus (pl.13). In both cartouches (nomen or prenomen) Augustus had kept his Roman epithets as Romaios (the Roman), Autokrator (emperor) and Sebastos (the August one). ${ }^{197}$

The halls of the sacrifice, the ennead, and the temple's sanctuary were decorated under the reign of Augustus. He consecrated the southern part of the temple for Isis, while the northern part was consecrated for the local god,

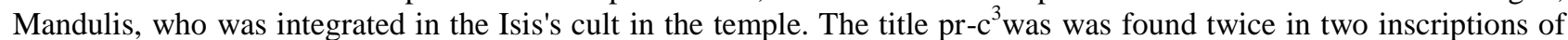
Augustus in the outer court and the pronaos of the temple dated back to the $2^{\text {nd }}$ year A.D. ${ }^{198}$ Augustus is depicted also on the northern wall of the sacrifice's hall, while being purified by Thoth and Horus (pl.14), and being crowned by Nekhbet and Wadjet (pl.15).

\section{Phila}

He shared in the building of the mammisi of Phila, ${ }^{199}$ which the eternal western wall of the mammisi was decorated by Tiberius. While the external eastern wall was decorated by Augustus himself, he is depicted on the external eastern wall of the naos of the mammisi as a complete pharaoh, with the blue crown of Egypt with all signs of royalty, holding the hk3-scepter and the flail in his left hand, before Isis and her son Harpocrates. ${ }^{200}$ He has the titles as:

"The king of Upper and Lower Egypt, the ruler of the two lands, Autokrator (=Imperator), Son of Re, lord of the crowns, Cesar, life forever, the beloved of Ptah and Isis".

Isis's donation as: "I give for you the palace, stay with your ka", while Harpocrates's donation as: "I give you Egypt". As a ward for Augustus for his special visit to Isis and Harpocrates at Phila, the text reads as:

"The good god, I run in a hurry to see the goddess-mother, the loveliness (beauty) of Isis, and the giver of life, to pray, she has the happiness in her sight, you will be happy when you see her, you heart will be satisfied by her agreement, your ka will be satisfied by this monument, she gives you the majesty, son of Re, Cesar, lives forever". ${ }^{201}$

The appearance of Augustus on the birth house of Phila emphasis that he was look for to be the incarnation of Harpocrates on earth, and the sons of Osiris and Isis. Augustus also was depicted on the main entrance of Hathor temple pleasing the heart of Isis by offering two sistrums (pl.16). The western colonnade of Isis's main temple was decorated under the reign of Augustus and Tiberius, two demotic graffiti refer to Augusts. Many scenes and inscriptions belonged to Augustus are inside the main temple of Isis. He is depicted on the external eastern, western and back wall of the naos.

Moreover, he was depicted on the eastern wall of the Pronaos, mainly with his Horus name. He is depicted on the back wall of the naos while making offerings before Isis (pls.17, 18), while the inscription refers that he had consecrated this monument for Isis as (ir.n.f mn.w n mw.t.f Is.t wr.t mw.t ntr.w). He built this monument to his mother Isis, the Great, the mother of the gods. ${ }^{202}$ Moreover, he was depicted on the third register of the eastern wall of the exterior wall of the naos leaves his palace as the Pharaoh, with the standard-bearers and the priest Imutef, then he is purified by Thot and Horus, and crowned by Nekhbet and Wadjet before Isis (pl.19). This emphasized that he will be the king of Upper and Lower Egypt according to the permission of goddess Isis, who had witnessed his coronation as an Egyptian pharaoh. Augustus also was depicted led by Re-Harachty and Montou to Isis. ${ }^{203}$

There is also an inscription on the external wall of the outer hall (the forecourt) of Hathor temple at Philaportrays Augustus with his Horus name as: Ir. $n=t$ nbt3.wy (3wdkrdr) s3R ${ }^{c} n b h^{c}$.w (Kysrs ${ }^{c} n h$ d.t mr ipth Is.t). ${ }^{204}$

"He made for you, king of Upper and Lower Egypt, lord of the two lands, Imperator, son of Re, lord of the crowns, Cesar, live forever, beloved of Ptah and Isis, he built the temple as a complete construction". ${ }^{205}$

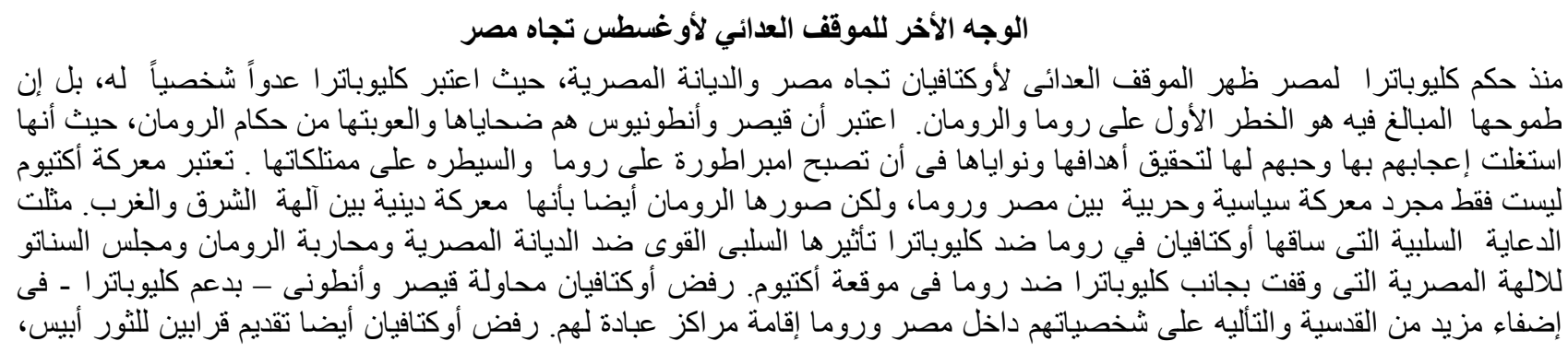


بإعتباره مجرد حيوان لا يجوز تأليهه؛ كما وقف ضد إو عبادة أيزيس ومنع إقامة معابد لها وأضطهد كهنتها وأتباعها فى روما. تغيرت سياسة

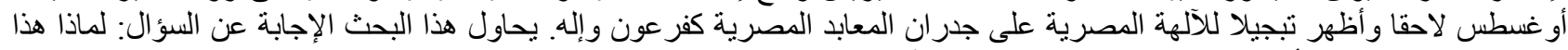

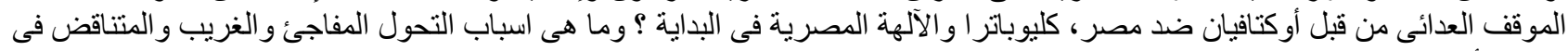

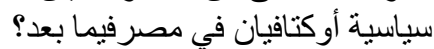

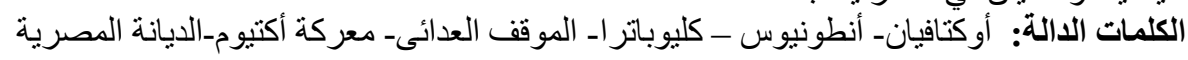

\section{Plates}

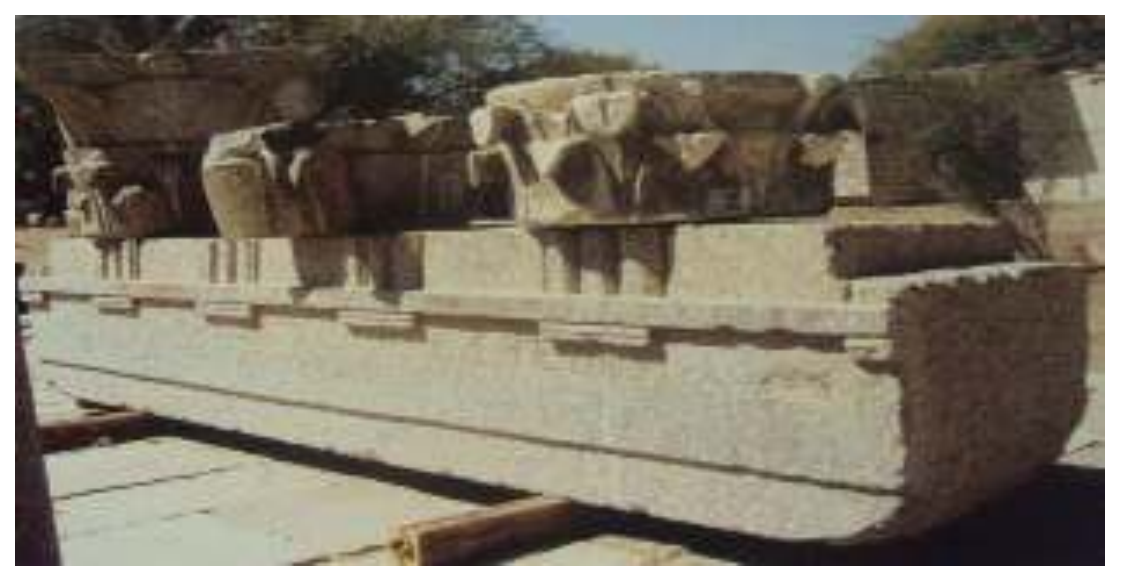

Pl.(1) Granite architrave next the Augustus's temple at Phila

Hölbl, G., Altägypten im Römischen Reich, Der römische Pharao und seine Tempel (I), Mainz am Rhein, 2000, fig. 19.

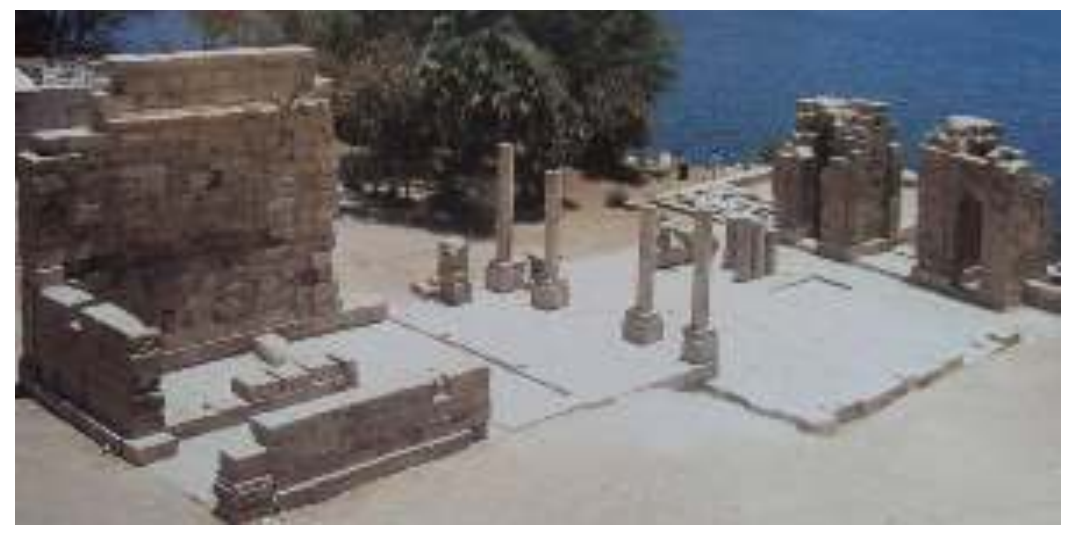

Pl. (2) Temple of Augustus at Phila.

Hölbl, G., Altägypten im Römischen Reich, fig, 18.

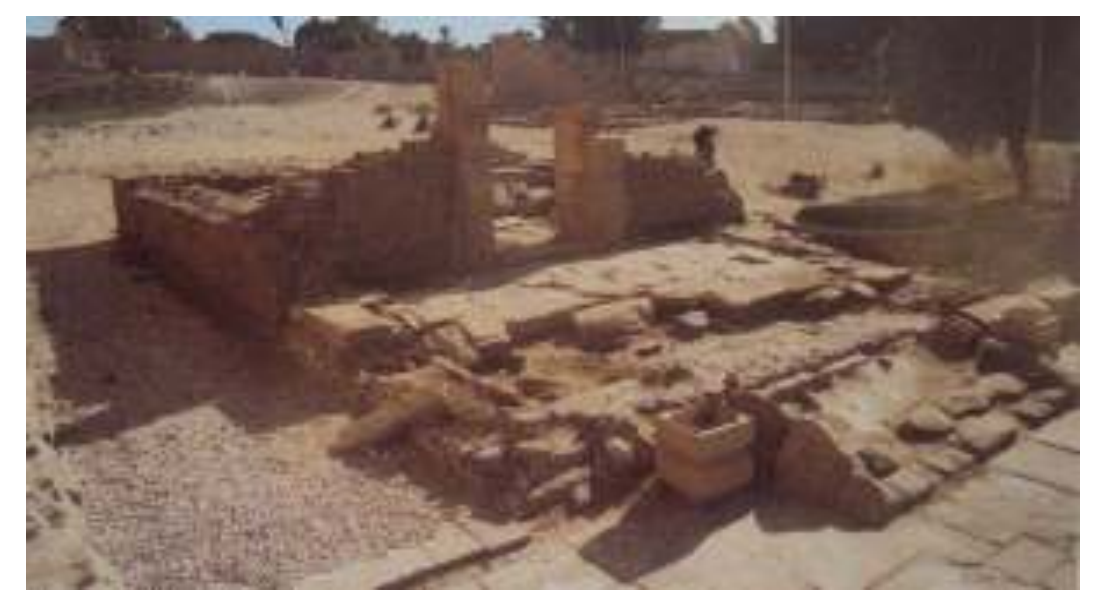

Pl. (3) Augustus's chapel at Karnak

Ibid, fig. 18 

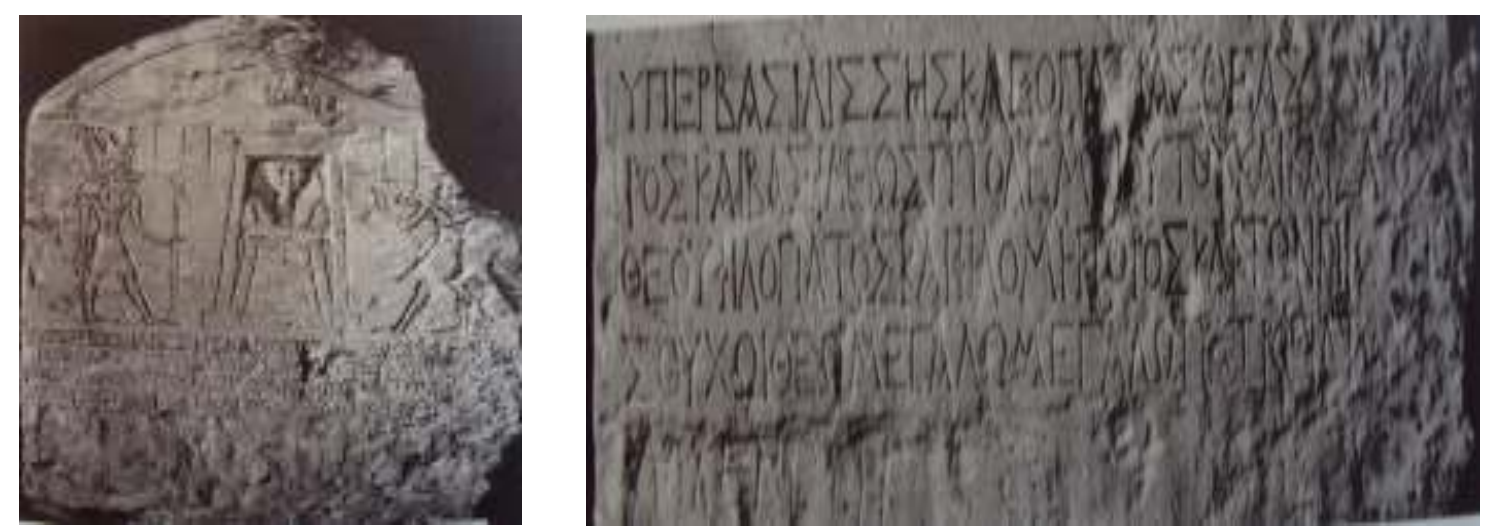

Pl. (4 ) The stela of Krokodilopolismm

Bernand, E., Recueil des Inscriptions Grecques du Fayoum, Vol (1), La“Meris“d” Herakleides, Leiden, 1975 , pp.45-47, pl.12

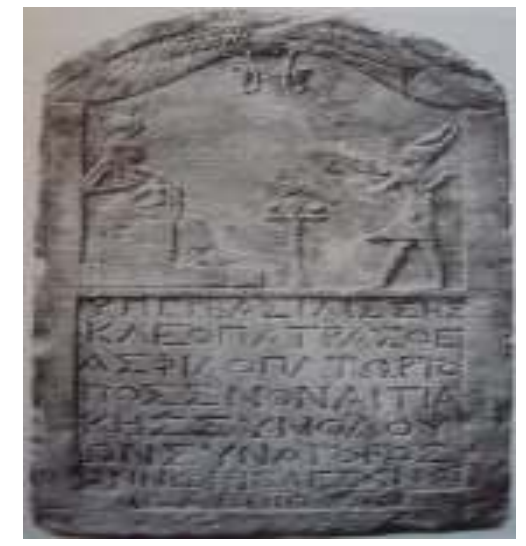

Pl. (5) Stela of Soknopaious- Nesos

Bernand, E., Inscriptions Grecques d'Egypte et de Nubie au Musée du Louvre, Paris, 1992, pl. 17.nr.21.

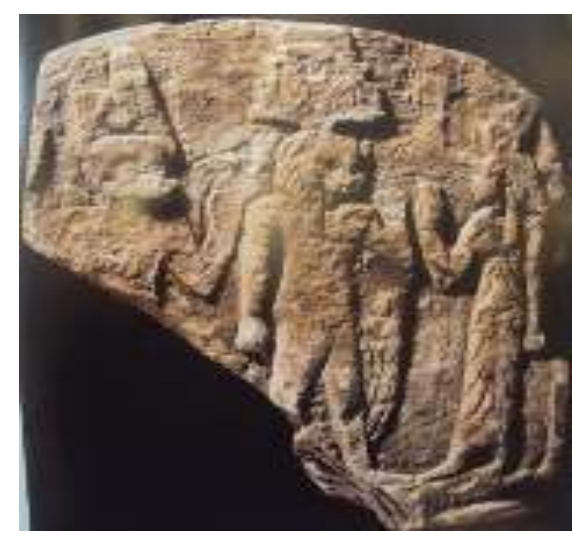

Pl.(7) Julius Cesar, Cleopatra VII and Caesareion as the triad of Thebes

Andrea, B., "Kleopatra und die historischen persönalichkeiten in ihrem Umkreis", in: Kleopatra und die Caesaren eine Ausstellung des Bucerius Kunst Forums, 28. Oktober 2006 bis 4. Februar 2007, München,2006,p.69, 38 Kat.16

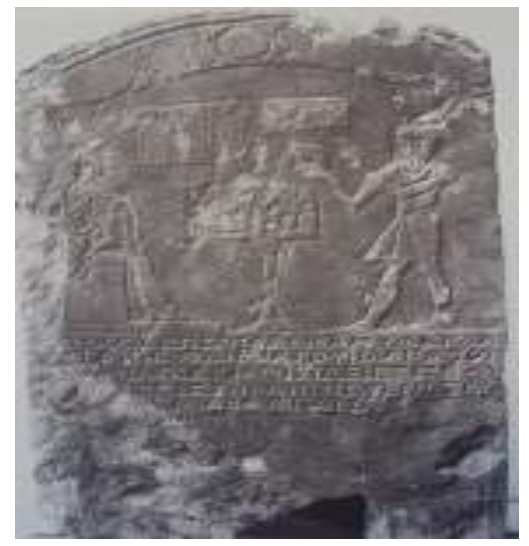

Pl.(6) Auletes before Isis of Chemmis Bernand, E., Recueil des Inscriptions Grecques du Fayoum, Vol (I), Leiden, pl.9

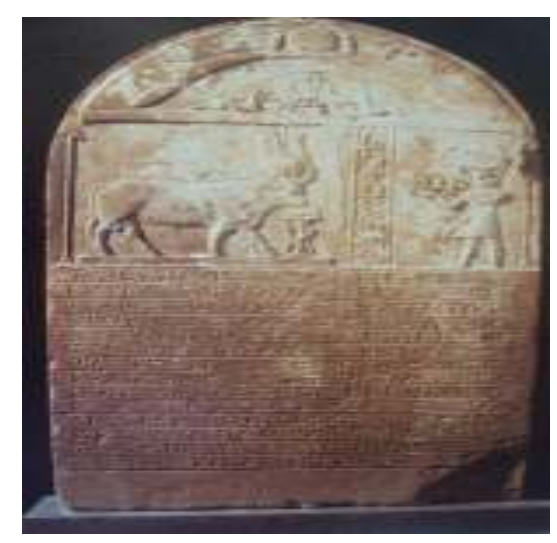

Pl. (8) Auletes before the Buchis bull Hölbl, G., Op. Cit, pl.9 


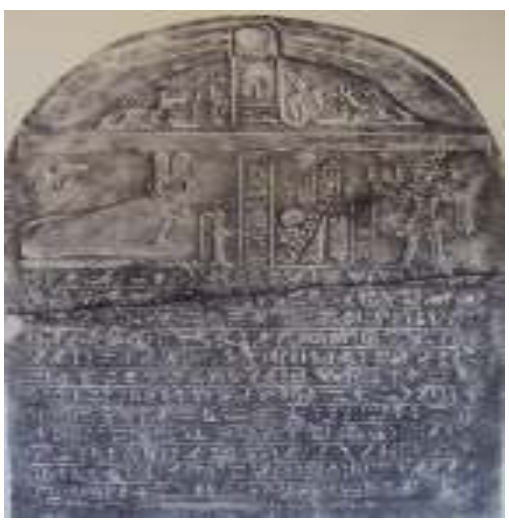

Pl.(9) Augustus before the Buchis bull Mond, R., the Bucheum (III), 1934, pl. XLIII.14

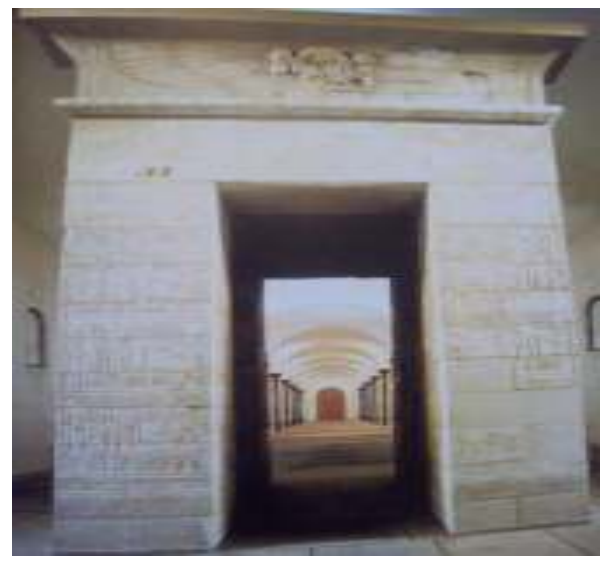

Pl. (10) The Kalabscha main gateway- the Egyptian Museum at Berlin; Hölbl, G., Op. Cit, fig.12

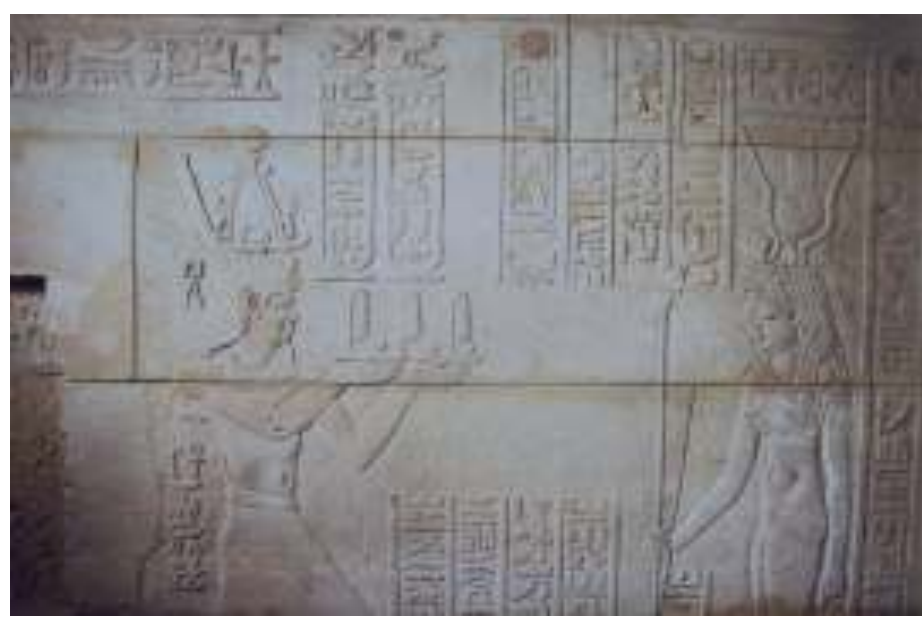

Pl. (11) Augustus is offering the Shyt before Isis- Kalabscha Ibid, fig. 13 .

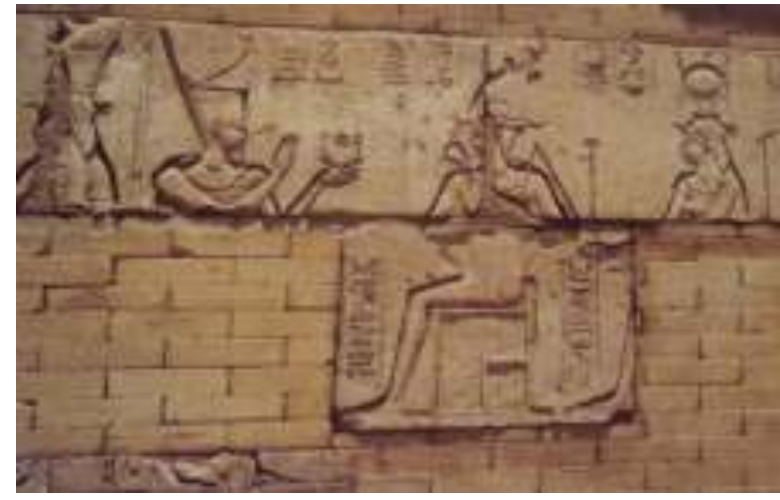

Pl. (12) Augustus is offering the religious symbols before Osiris and Isis- Kalabsha, Ibid, fig.15

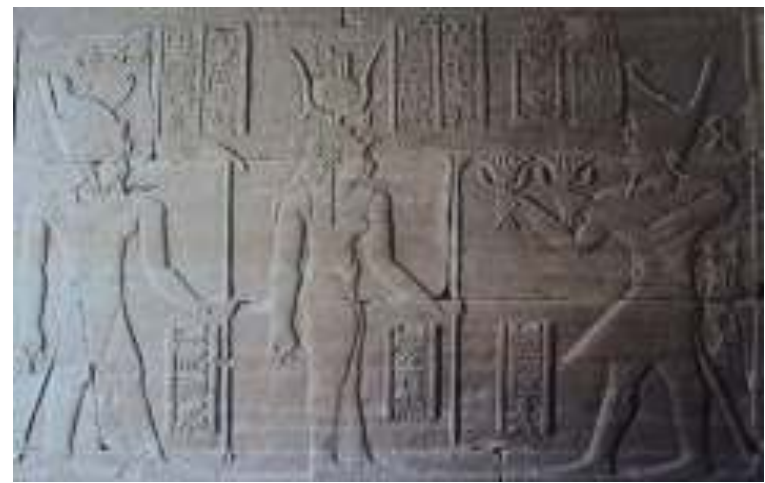

Pl.(13) Augustus is offering two Lotus flowers before Isis and Harpocrates- Kalabscha Hölbl, G., Altägypten im Römischen Reich, Der römische Pharao und Seine Tempel (II), Die Tempel des römischen Nubien, Mainz am Rhein, 2004, fig. 185 


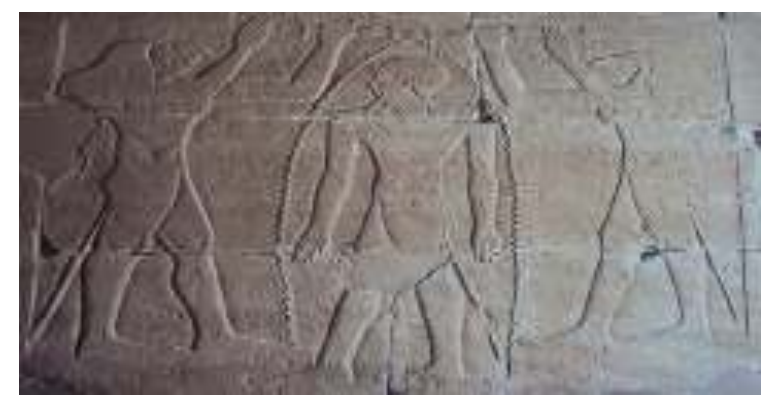

Pl.(14) Augustus is purifying by Horus and Thot- The middle scene of the lower register of the northern wall of the sacrifice room, Kalabscha temple, Ibid, fig. 173

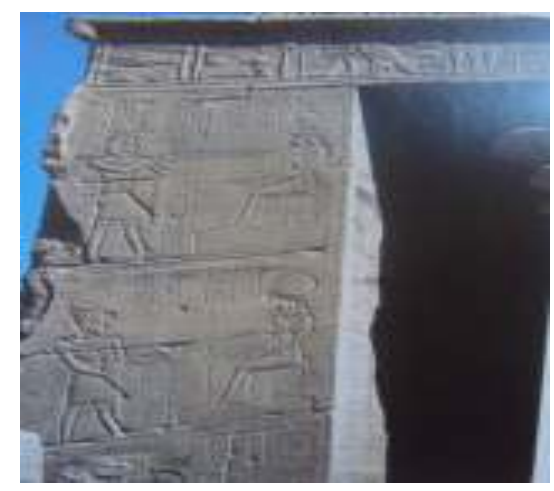

Pl. (16) Augustus with the sistrum before Isis, the left ante of the façade of Hathor temple at Phila; Ibid, fig. 116.

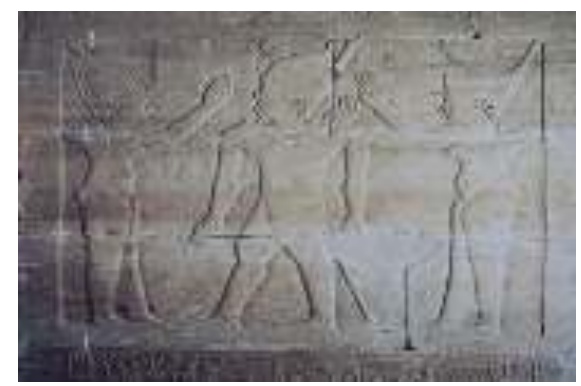

Pl.(15) Nekhbet and Wadjet are crowning Augustus- The lower register of the northern wall of the first room of the Naos- Kalabscha, Ibid, fig. 174

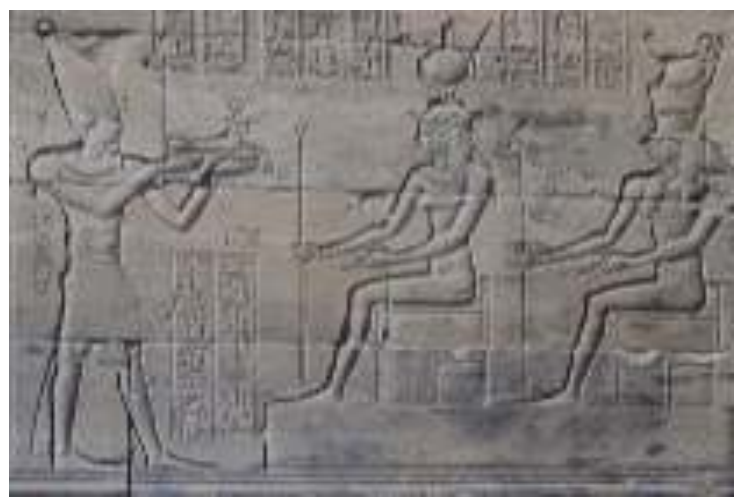

Pl. (17) Augustus is offering the Menit before Isis and Horus, the upper register of the eastern exterior wall of the naos of Isis temple at Phila; Ibid, fig. 108

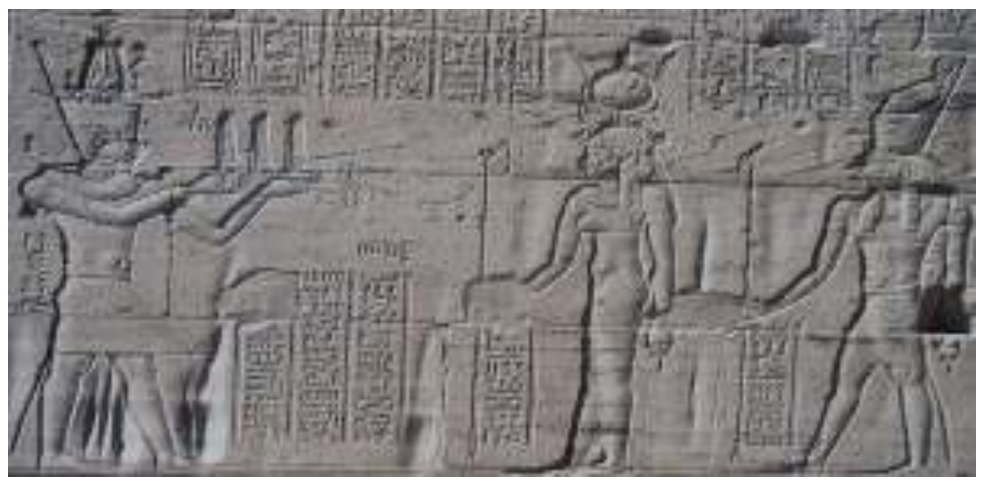

Pl. (18) Augustus is offering the Shyt before Isis and Horus, the lower register of the eastern exterior wall of the naos of Isis temple at Phila; Ibid, fig. 106.

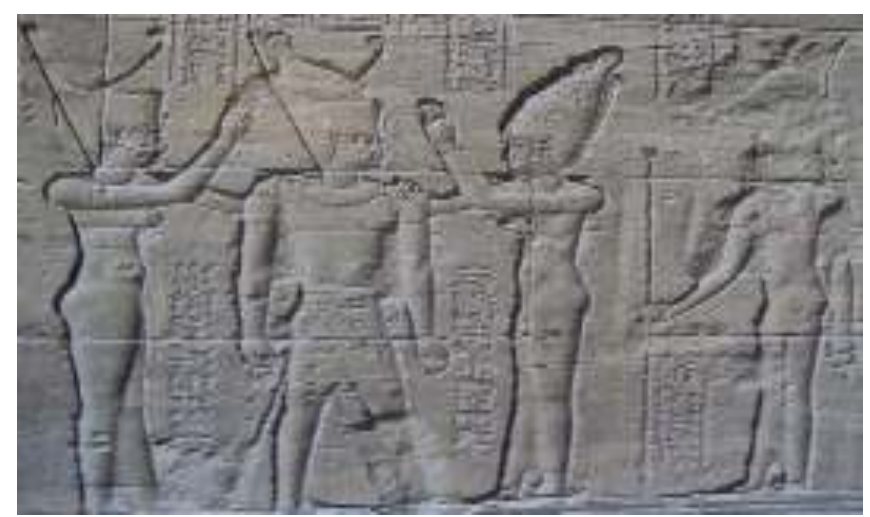

Pl. (19) Nekhbet and Wadjet are crowning Augustus before Isis, the lower register of the eastern exterior wall of the naos of Isis temple at Phila, Ibid, fig.105. 


\section{Endnotes}

1 Dio Cassius. 50.24,6f

2 Fowler, D., "Virgil (PubliusVergiliusMaro)" in The Oxford Classical Dictionary, (3.ed), Oxford. 1996, p.162.

3 Dunand, F., "Problèmes et Controverses", in: Hommes et Dieux en Egypte (300 a.c -395 p.c), (ed.by Dunand, F and Zivie- Coche, C), Paris, 2006, p. 351.

4 Dio Cassius. 50. 4,5; Binder, G., Aeneas und Augustus. Interpretationen zum 8. Buch der Aeneis, Beiträge zur Klassischen Philologie, (Herausgegeben von Merkelbach, R), Meisenheim am Glan, 1971, pp.219, 234.

5 Huzar, E., "Emperor Worship in Julio- Claudian Egypt”, in: ANRW (II/ 18.5), New York, 1995, p. 3118

6 Binder, G., Op.Cit, p.234; Propertius. 3.11,31; Hemelrijk, E. and Smelik, K , "Who knows Not What Monsters Demented Egyptian Worship", in: ANRW (17,4), 1984, p. 1854.

7 Cleopatra was worshipped as Isis. Plut.Anthony. 54, 6;Di Cassius. 50.5. 3; 50.5,3; Binder, G., Op. Cit, p.216; Hemelrijk, E and Smelik, K.., Op. Cit, p. 1854.

8 Malaise, M., Les Conditions de pénétration et de Diffusion des CultesEgyptiens en Italie, EPRO (22), Leiden, 1972, p. $246 f$.

Hemelrijk, E and Smelik, K.,Op. Cit, p. 1929.

${ }^{10}$ Ovid, Metamorphoses, XV, 826-828.

11 Propertius, III, 11, 33-34, 39-43.

12 Vergil, Aenead, VIII, 688, 696, 711, 698-699. See Yehya, L., “Alexandria and Rome in Classical Antiquity. A Cultural Approach", in: Roma e l'Egittonell' AntichitaClassica, Cairo, 6-9 Febbraio 1989, Atti de I CongressoInternazionaleItalo- Egiziano, Roma, 1992, p. 357.

13 Dundas, G., Pharaoh, Basileus and Imperator: the Roman Imperial Cult in Egypt, Ph. D unpublished. Diss.,Los Angeles, 1994, p. 97. About the imperial cult at Asia Minor see: Friessen, S., Twice Neokoros: Ephesus, Asia and the Cult of the Flavian Imperial Family, Leiden, 1993; Price, S., Rituals and Power: The Roman Imperial Cult in Asia Minor. Cambridge, 1984.

14 See: Taylor, L., The Divinity of the Roman Emperor, APA Monograph Series, I, Middletwon, 1931.

15 Dundas, G., Op. Cit, pp. 29-30; see also Latte, K., Römische Religionsgeschichte, Handbuch der Altertumwissenschaft, (ed. B. Bengston, H), Munich, 1960.

16 Mellor, R., "The Goddess Roma", in: ANRW (2.17.2), 1981, pp. 950- 1030.

17 Fayer, C., ilCultodellaDea Roma: Origineet Diffusion nell'Impero, Pescara, 1976, pp. 112-123; Pfeiffer, S.,"The Imperial Cult in Egypt", in: the Oxford Handbook of Roman Egypt, Oxford, 2012, p. 85.

18 Bowman, A., Egypt after the Pharaohs: 323 B.C - A.D 642, from Alexander to the Arab Conquest. Berekely and Los Angeles, 1986, pp. 166, 217.

19 Otto, W., Priester und Tempel in Hellenistichen Ägypten, Vol (1), Leipzig, 1905, p. 11

20 See: Blumenthal, F., "Der ägyptische Kaiserkult", in: AFP (3), 1913, pp. 326, 329ff. In an epigram on a statue of Apollo found in Egypt, Augustus is named as "Zeus Eleutherios" and "Zeus Augustus", who came to Egypt "with the cargo of good, lawful order and prosperity of utmost wealth". Geraci, G., GenestidellaProvinciaromanod'Egitto, SSA (9), Bologna, 1983, p. 154. Augustus also was entitled as "Zeus, the Deliverer". Minas- Nerpel, M and Pfeiffer, S., "Establishing Romans Rule in Egypt: The Trilingual Stela of C. Cornelius Gallus from Philae", in: Tradition and Transformation Egypt under Roman Rule, Proceeding of the International Conference, Hildesheim, Roemer, and Pelizaeus- Museum, 3-6 July 2008, Culture and History of the ancient Near East (41), (ed. by Lembke, K et al), Leuven, 2010, p. 283. Also an inscription at Dendera refers to Augustus as "Zeus Eleutherios". At Antinoupolis was a temple for a Greek worship of Augustus as a Greek ruler, and an Egyptian priest was responsible for the cult as “Augustus Zeus Eleutherios"..Pfeiffer, S.,"Der römische Kaiser und das Land am Nil, Kaiserverehrung und Kaiserkult in Alexandria und Ägypten von Augustus bis Caracalla (30 v. Chr.- 217n. Chr.)”, in: Historia(212), Stuttgart, 2010, pp.54,55-57.

21 Dundas, G., Op.Cit, pp. 20-21.

22 Dunand, F., "Culte royal et Culte Imperial en Egypte: Continuités et reptures", in: DasrömishebyzantinischeÄgypten, Akten des internationalen Symposiums 26. - 30. September 1978 in Trier, 1-6. Mainz am Rhein: Philipp von Zabern, 1983, pp.47-56.

${ }_{23}$ Rose, L., Sun, Moon, Sothis, A Study of Calendars and Calendar Reforms in Ancient Egypt, Vol. (2), Lynn E. Rose, 1999, p. 80.

24 Bari, S., "Economic Interests of Augustan Rome in Egypt", in:Roma, p. 70.

25 Dio Cassius. 51.17,1 (Translation by E. Cary, Loeb); Minas- Nerpel, M and Pfeiffer, S., Op. Cit, pp. 278-279.

26 Jones, A., A History of Rome through the Fifth Century, Vol. (II), p. 276.

27 Winter, E., “Alexander der Große als Pharao in ägyptischen Tempeln (Kat. 112-113)“, in: Ägypten Griechenland Rom: Abwehr und Berührung, (ed. by.In Beck, H et al), Frankfurt am Main, 2005, pp.204-205

28 Pfeiffer, S., Der römische Kaiser, p. 45.

29 Suet. Aug. 94, 4.

30 Suet. Aug. 94.5; Pfeiffer, S., Op. Cit, p.47. 
31 Grandet, P., «Les Songes d'Atia et d'Octavius. Note sur les rapports d'Auguste et de L'Egypte ». in: Revue de l'Histoire des Religions (203), 1986, pp.3176-3177; Kiensant, D., Augustus und Alexander', in: Raban vonHaehlingu.a. (hg.), Dietmar Kienast. Kleine Schriften, Alaen 1994, p.327.

32 Suet. Aug. 94,5; Pfeiffer, S., Op. Cit, pp.47-48.

33 Gruen, E., "Augustus and the Ideology of War and Peace", in: the Age of Augustus, (ed. by. Winkes, R), Providence, 1985, p.71.

34 Hausmann, U., Zur Typologie und Ideologie des Augustusporträts“, in: ANRW (II, 12,2), 1981, pp.537-538.

35 Grandet, P., Op. Cit, pp.370-375; Heinen, H., Vorstufen und Anfänge des Herrscherkultes im römischen Ägypten, in: ANRW (II,18,5), 1995, p.3174.

36 Crawford, D., "Ptolemy, Ptah and Apis in Hellenistic Memphis", in: Studies in Ptolemaic Memphis (ed. by Crawford, D), in: StudiaHellenistica (24), Leuven, pp. 1-42; Thompson, D., Memphis under the Ptolemies, Princeton, 1988.

37 Herklotz, F., "AegyptoCapta, Augustus and the Annexation of Egypt", in: the Oxford Handbook of Roman Egypt, Oxford, 2012, p. 13.

38 Pfeiffer, S., Der römische Kaiser, p. 49.

39 Grandet, P., Op. Cit, p. 374; Heinen, H., Op. Cit, p. 3175.

40 The statue of Apollo at the Capitoline carries the facial features of Augustus. See Pfeiffer, S., Op. Cit, pp. 57-58.

41 Pfeiffer, S., Op. Cit, p. 49; Grenier, J., Le Prophete et l'Autokrator “, in: RdE (37), 1985, pp. 81-89

42 Huzar, E., Op.Cit,p. 3118

${ }^{43}$ Ibid, pp.3114-3116

44 Ibid, p. 3119

45 Ibid,p. 3119

46 Iversen, E., "Egypt in Classical Antiquity", in: Hommages a Jean Leclant, Vol. (3), Etudes Isiaques, IFAO, 1994, p. 301

47 BM, EA. 188, lines 4-5.

48 Crawford, D., Stud. Hellen. (24), p. 41. Two stelae in Demotic and Hieroglyphics now in the British Museum EA 188, 184 belong to Petubastis and his wife. For the stelae see: Quaegebeur, J., "Contribution a la prosopographie des PretresmemphitesaépoquePtolemaique”, in: Ancient Society (3), 1972, pp. 77-109; Young, T., Hieroglyphics Collected by the Egyptian Society, Wiesbaden, 1982, pp. 70-74; Herklotz, F., Prinzeps und Pharao: Der Kult des Augustus in Ägypten, Frankfurt, 2007, pp. 294-297.

49 Thompson notes that the high priesthood of Memphis became after Psenamunis a non- hereditary office of limited tenure. Thompson, D., Memphis under the Ptolemies, p.272.

50 Herklotz, F., AEgyptoCapta, p. 14.

${ }^{51}$ Crawford, G., StudiaHellenistica (24), pp.41-42.

52 The Galliusstela is a trilingual inscription, hieroglyphic- Latin and Greek, dated to 16 April 29 B.C, of pink granite commemorate the victory of the Roman perfect Gallius on the Nubians, re-discovered in 1896 in front of August's temple at Phila, cut into two parts, the stela had been reused in the foundations, presumably the temple's altar. It is now in the Egyptian Museum in Cairo (CG 9295). Erman, A., EinetrilingueInschrift von Phila", in: SPAW (20), 1896, pp.469-470'; Bernand, A., Les Inscriptions grecquesetLatine des Philae, II, Haut et Bas Empire, 1969, no.140; MinasNerpel, M and Pfeiffer, S., Op. Cit, pp. 265-295.

53 Minas- Nerpel, $\mathrm{M}$ and Pfeiffer, S., Op. Cit, p.273.

54 He also did not appear with the Greek title Basilios in his inscriptions. Herklotz, F.,Prinzeps und Pharao, p. 136.

55 Ibid, p. 3120

56 Hölbl, G., "Ideologische Fragen be der Ausbildung der römische Pharaoh", in: Weg Öffnen: Festschrift fur Rolf Gundlach zum 65. Geburtstag. Wiesbaden, 1996, pp. 100-105.

57 The title was mentioned also on a dorsal pillar of a statue of pakhom of Mendes. The title was used by Nero and Vespesian. Grenier, J., Le Prophete et l'Autokrator“", pp. 81- 82.

58 The Horus name became very long and maintained in this form for the later Roman emperors. The full version of the name was mentioned seven times, while twenty-three times was mentioned in abbreviated manner. Grenier, J., Les titulatures des empereurs romains dans les documents en langue égyptienne, Brussels, 1989; Herklotz, F., PrinnzepsundPharao, pp.413-421.

59 Herklotz, F., Op. Cit, pp.14-15.

${ }^{60}$ Bell, H., Egypt from Alexander the Great to the Arab Conquest, Oxford, 1984, p.68; Parassoglou, M., A Prefectural edict regulating Temple Activities", in: ZPE (13), 1974, pp.32-37.

61 Blumenthal, F., " Der ägyptische Kaiserkult", in: AfP (5), Leipzig, 1913, p.317f; Hemelrijk, E and Smelik, K., Op. Cit, p. 107.

${ }^{62}$ Augustus's affront posed difficult theological problems for the Egyptian priests, which carried over to the economic and administrative level. The Idios Logos started from the reign of Augustus till the reign of Trajan or Hadria, the decree was taken over. Kockelmann, H., "Sobek und die Caesaren, Einig Bemerkungenzur Situation der Krokodil götter kulte des Fayoum unter Römischer Herrschaft", in: Tradition and Transformation under Roman Rule,pp. 204-214. 
63 Stead, M., "The High Priest of Alexandria and all Egypt", in: Proceeding of the $16^{\text {th }}$ International Congress of Papyrology, Chico, 1981, p. 411; Pfeiffer, S., The Imperial Cult, pp. 92-94.

64 Huzar, E., op. Cit, p. 3123

65 Pfeiffer, S., Op. Cit, p.93.

66 Dundas, G., Op. Cit, pp. 113- 115.

67 Pfeiffer, S., Op. Cit, p. 97.

68 Huzar, E., Op. Cit, p. 3122

69 Dunand, F., "Culte royal et Culte impérial en Egypte. Continuites et reptures", in: Das Römisch-Byzantinische Ägypten, Akten des internationalen Symposions 26,-30. September 1978 in Trier, Mainz am Rhein, 1983, p.53

${ }^{70}$ Gradel, I., Emperor Worship and Roman Religion, Oxford, 2002, p. 27

71 Klotz, D., Caesar in the City of Amun, Egyptian Temple Construction and Theology in Roman Thebes, MRE (15), Turnhout, 2012, p. 235

72 For the Caesareum see: Herklotz, F., Prinzeps und Pharan, pp. 267-272. The Caesareum was described first by Strabo (Geography 17.1.10) indicates that it exists by 26-20 B.C, thus, by this date there was a substantial temple in the city dedicated for Augustus- not Cesar- there is uncertainty about whether its construction was begun in honor of Julius Cesar or Mark Antony by Cleopatra. Strabo mentioned that the Caesareum located in front of Cleopatra's obelisk (originally of Tuhtmosis III at Heliopolis and was brought by Augustus at Alexandria), which stood in front of it facing the harbor. For more information see Mckenzie, J., The Architecture of Alexandria and Egypt, 300 B.C to 700 A.D, Yale University Press, New Haven and London, 2007, pp. 177-179. Pliny locates these obelisks at the entrance to the "temple of Caesar". He gives their height as 42 cubits (22, $5 \mathrm{~m}$ ). Pliny, Natural History, 36.14.69.42, which notably, is close to their actual height (ca. 21m). Later the Philosopher Philo of Alexandria in 38 A.D -during the life time of Caligula- as "No such sanctuary exists anywhere else.... Situated on an artificial hill.... A temple of dimensions unknown in any other place, with votive offerings, including paintings and statues in gold and silver... embellished with porticoes, libraries, rooms, gardens, portals and large open courtyards". Philo of Alexandria, Legatioad Gaium (15). The Caesareum was mentioned also by Neroutsos Bey in 1874, that the walls of the structure having a thickness of 3.5 and $2.5 \mathrm{~m}$. Cleopatra had wanted to outshine the nearby and imposing Serapeum, because nothing was too beautiful or great enough for the father of Cesarion. Goudchaux, G., "Cleopatra's Subtle Religious Strategy", in: Cleopatra of Egypt, from History to Myth, (ed. by Walker, S and Higgs, P), London, 2001, pp.136. The Cesareum was subsequently rededicated to Augustus and referred to as the "temple" or "shrine" (Caesaistemplum, or Caesareum Magnum). For more details about the Caesareum see Pfeiffer, S., "The Imperial Cult in Egypt", in: the Oxford Handbook of Roman Egypt, pp.8687. About the Caesareum and Cleopatra's needle See Empereur, J., Alexandria Rediscovered, London, 1998, pp.111124.

73 Sebastos was the Greek translation of the title Augustus, was later used by the Roman Emperors. That Augustus was worshipped in the Kaisareion as "Kaiser Epibaterios".

74 Venit, M., "Alexandria“, in: The Oxford Handbook of Roman Egypt, p. 111. Haas refereed that Aphrodite was worshipped inside the Caesareum. Haas, C., Alexandria in Late Antiquity: Topography and Social Conflict. John Hopkins University Press, 1997, p.144

75 Pfeiffer, S.,Der römische Kaiser, p.237.

76 McKenzie, J., Op. Cit, p. 177; about the worship of Caesar in Alexandria see Merriam, A., "The Caesareum and the Worship of Augustus at Alexandria", in: TAPA (14), 1883, pp. 5-35.

77 Pfeiffer, S.,"The Imperial Cult in Egypt", p. 87.

78 The obelisks were transported by Augustus in 12 B.C to be erected in front of the Caesareum, the obelisks were erected first by Tuhtmosis III, then usurped by Ramesses II, and have become known as Cleopatra's needles. These two obelisks, one was presented by Mohamed Ali to the British nation in 1819, which the British nation refused first the present for the problem of the transport from Egypt to England, then was abandoned during a storm in its sea voyage to London in the Bay of Biscay on October 14, 1877. Two years later was recovered and erected on the banks of the Thames. The other one was given to the City of New York at the opening of the Suez Canal in 1869 by the Khedive Ismail and erected in Central Park in January 1881. Venit, M., " Ancient Egyptomania: The Uses of Egypt in GrecoRoman Alexandria", in: Leaving No Stones Unturned: Essays on the Ancient Near East and Egypt in Honor of Donald P. Hansen, (ed. By. Ehrenberg, E), Winona Lake, 2002, pp.268-269, note. 29, see also: D' Alton, M., The New York Obelisk or How Cleopatra's Needle came to New York and what happened when it got here, reprinted from the Metropolitan Museum of Art Bulletin, 1993. The fallen one now on the Thames Embankment in London, while the standing one in the Central Park in New York. Their orientations indicate that they were not oriented on the city grid plan, but at an angle to it. This suggests that (even if its enclosure was on the grid) the temple was also positioned at this angle to the grid, to make it easier to view as ships came into the harbor, steering around Antirrhodos. McKenzie, J., Op. Cit, p. 177.

79 Alföldy, G., "Der Obelisk auf dem Petersplatz in Rom: Ein historisches Monument der Antike, Heidelberg, 1990, p. 87. The forum Iulium was later known as forum Augusti, when Cesar took his new title as Augustus, it must therefore have been an open space located at the temple of Augustus. Ibid, pp.41-42. May be the forum Augusti was renamed 
after 27 B.C .During the expansion of the temple itself on the space around the Caesareum. Pfeiffer, S., the Imperial Cult, p. 87.

80 Pfeiffer, S., the Imperial Cult, p. 87.

81 Ibid, p. 87.

82 About the Caesareumsee: Sjöqvist, E., "Kaisareion, A Study in Architectural Iconography", in: Opscularomana (1), 1954, pp.86-89; Fishwick, D., "The Temple of Caesar at Alexandria", in: AJAH (9), 1984, pp.131-134; id., "the Caesareum of Alexandria Again”, in: AJAH (12), 1987, pp.62-72.

83 Other temples were erected on the harbor of Alexandria for the sailors, as the temple of Isis- Pharia, the temple of Arsinoe on the coast of Alexandria. See Fraser, P., Ptolemaic Alexandria, Vol. (1). Oxford, 1972, p. 21

84 Isis- Euploia, the goddess who holds a rudder in her left hand and two ears of wheat in her right, as a significant of the successful arrival of the grains to Rome. Milne, J., Catalogue of Alexandrian Coins, Oxford, 1971, nos. 2288-91.

85 Dundas, G., Op. Cit, pp. 152-154. The Kaisareion of Alexandria with its two fundamental obelisks as a symbol of savior for the sailors was assimilated with the building of the lighthouse of Ptolemy Soter, and his god's patron, Zeus Soter, which was an indicator for the welfare of the Sailors. Dundas, G., Op. Cit, pp. 265-267.

${ }^{86}$ Dessau, H., Inscriptions Latina e Selectae, Vol. (3), 1916, part.3, no. 9059; Ward-Perkins, J and Balance, M., The Caesareum at Cyrene and the Basilica at Gremna", in: PBSR (26), 1958, p.176.

87 Adriani, A., Repertorio d' Arte dell' Egitto Greco- romano, Palermo, 1966, p.217; P. Oxy VIII.1116, 9-11; Dundas, G., Op. Cit, pp.153-154.

${ }^{88}$ Pensabene, P., “Architettura Imperiale in Egitto", in: in: Roma e l'Egitto, p. 275.

89 Pfeiffer, R., Der römische Kaiser, pp. 241-242; Dundas, G., Op. Cit, p. 88. A shrine attributed to Augustus attached to the temple of Anubis and Leto in the Cynopolitenome to syncretistic portraits of gods such as Horus and Amon in imperial for of Augustus. P. Oxy. X 1256 (282 AD); Glare, P., "the Temple of Jupiter Capitolinus at Arsinoe and the Imperial Cult", in: Proceedings of the $20^{\text {th }}$ International Congress of Papyrologists, Copenhagen, 23-29 August, 1992, p.553.

90 Dundas, G., Op. Cit, pp. 174-177.

91 OGIS. II. 657.

92 For the temple of Augustus at Phila see: Garston, W., A Report on the Island and Temples of Philae, with an Introduction note, London, 1896, pp.29-30; Herklotz, F., Op. Cit, pp. 273-275.

93 Hänlein- Schäfer, H., Veneratio Augusti, Eine Studie zu den Tempeln des ersten römischen Kaisers, Archaeologia (39), Roma, 1985.

94 Pfeiffer, S., Der römische Kaiser, pp. 242-243.

95 Klotz, D., Op. Cit, pp.236-237

${ }^{9}$ Pfeiffer, S., the Imperial Cult, pp. 89-90.

97 Wildung, D., Imhotep und Amenhotep, Gottwerdung im alten Ägypten, MÄS (36), 1977, pp.251-255, pl. LXIV.157; id., Egyptian Saints, Deification in Pharaonic Egypt, New York, 1977, pp.107-108, fig.63

98 Klotz, D., Op. Cit, p. 232.

99 Ibid, p. 237

${ }^{100}$ About these statues see: Thiers, C.,"Deux Statues des DieuxPhilometors a Karnak, KarnakCaracol R 177+ Cheikh Labib 94CL1421 et Caire JE 41218)“, in: BIFAO (102), 2002, pp. 389-404; Laufray, J.,"Notesur les Portes du 1 er Pylon de Karnak“, in: Kemi (20), 1970, pp. 101-110; id.,"Abordsoccidentaux du premier Pyoln de Karnak, le Dromos, la Ritual et les Amenagement portuaires“, in: Kemi (21), 1971, pp. 77-144

${ }^{101}$ Klotz, D., Op. Cit, p. 328

${ }^{102}$ Yoyotte, J and Charvet, P., Strabon, le Voyage en Egypte, Un regard romain, Paris, 1997, p.188; Locher, J., "Die Anfänge der römischen Herrschaft in Nubien und der Konflikt zwischen Rom und Meroe“, in: AncSoc (32), 2002, pp.77-79

${ }^{103}$ Klotz, D., Op. Cit, p. 239

${ }^{104}$ Herklotz, F., Prinzeps und Pharao, p. 273; Klotz, D., Op. Cit, p. 239

${ }^{105}$ Schenk, R., Der Korinthische Tempel bis zum Ende des Prinzipates des Augustus, Archäologie (45), Espelkamp, 1997, pp. 61-62.

${ }^{106}$ Herklotz, F., Prinzeps und Pharao, pp.275-282 .

${ }^{107}$ Pfeiffer, S., the Imperial Cult, p.91.

${ }^{108}$ Iversen, E., Op. Cit, p.301.

${ }^{109}$ Casson, L., "The Isis and her Voyage", in: TAPA (81), 1950, pp.43-56; Lord, L., "The Date of Julius Cesar's Departure from Alexandria", in: JRS (28), 1938, pp.22-23.

110 Aly, A., "Cleopatra and Caesar at Alexandria and Rome", in: Roma e l'Egitto, p.52.

${ }^{111}$ Volkmann, H., Cleopatra, London, 1958, p.80.

112 Aly, A., Op. Cit, p.52.

${ }^{113}$ Bianchi, R., “ Ptolemaic Egypt and Rome”, in: Cleopatra's Egypt, Age of the Ptolemies, the Brooklyn Museum, 1989, p. 19 
${ }^{114}$ Williams, J., "Spoiling the Egyptians": Octavian and Cleopatra", in: Cleopatra of Egypt from History to Myth, pp.193-194.

115 Goudchaux, G., Op. Cit, p.139.

116 Suetonius, Iul.52.

${ }^{117}$ Caesar didn't declare his paternity to the son officially, but privately among his intimate friends and devoted adherents. Aly, A., Op. Cit, p. 50.

${ }^{118}$ Ibid, pp.50-51.

${ }^{119}$ Ibid, p.55.

${ }^{120}$ Bianchi, R., Op. Cit, pp. 19-20

${ }^{121}$ Ibid., p. 60

${ }^{122}$ Williams, J., Op. Cit, pp. 196-199.

${ }^{123}$ See: Etman, A., "Cleopatra and Egypt in the Augustan Poetry", in: in: Roma e l'Egitto, pp. 161-175.

${ }^{124}$ The stela is now in the Egyptian Museum nr. 40720. It is $45 \mathrm{~cm}$ high, $31 \mathrm{~cm}$ wide, and $17 \mathrm{~cm}$ thick about the stela see: Lefebvre, G., "Egypte- Greco- Romaine", in: ASAE (IX), 1908, pp. 240-242; Bernand, E., Recueildes Inscriptions Grecques du Fayoum, Tom. (I), Leiden, 1975, pp.45-47, pl.12. Heinen, H., Kleopatra- Studien, Gesammelte Schriften zur ausgehenden Ptolemäerzeit, Konstanz, 2009, pp.244-248; id., "Vorstufen und Anfänge des Herrscherkultes im römischen Ägypten", in: Vom hellenistischen Osten zum römischen Westen, Ausgewählte Schriften zur Alten Geschichte, Stuttgart, 2006, pp. 159-162

${ }^{125}$ In the year 16 of her reign (37/36 B.C) was considered as a new coronation year of Cleopatra as year 1 of her reign, the epithets proclaims Cleopatra VII as a spiritual heir to Cleopatra Thea, the great queen of Syria. Then Alexandria modified Cleopatra's titulature as "Theaneoteraphilopatorkaiphilopatris" (goddessneotera who loves her father and loves her patris). While Cesareon was entitled also as "God who loves his father and loves his mother). For more information see: Bingen, J.," Cleopatra VII Philopatris", in: Hellenistic Egypt, Monarchy, Society, Economy, Culture, (ed. by Bagnall, R), Edinburgh University Press, 1998, pp.57-62; id., "The Dynastic Politics of Cleopatra VII", in: Hellenistic Egypt, Monarchy, Society, Economy, Culture, pp. 75-76.

${ }^{126}$ Julius Caesar als Vater des Ptolemaios XV.Heinen, H., "Julius Caesar als Vater des Ptolemaios XV. Kaiser (Kaisarion)", in: Vom hellenistischen Osten zum römischen Westen, Ausgewählte Schriften zur Alten Geschichte, Stuttgart, 2006, pp.161-162Kaiser (Kaisarion), pp.161-162.

${ }^{127}$ The title was related also to the sons of Cleopatra, especially Cesarieon, who was known as basileusbasileon, while Cleopatra was known as "Queen of the kings". Grenier, J., Le Prophèteet l'Autokrator", pp. 82-83; id., Notes sur l'Égypte romaine (I, 1-7)”.in: Cd'É (63), 1988, p. 76.

${ }^{128}$ This is well-appeared among the numerous scattered temple blocks found at the Greco- Roman temple of Tod, several have recently been identified as belonging to Augustus, just as Armant, Medamud and Khonsu temple. Koltz, D., Caesar in the City of Amun, Egyptian Temple Construction and Theology in Roman Thebes, MRE (15), Belgium, 2012, p.245.

${ }^{129}$ It may be that Ptolemy XV takes his Roman title as Cesar during the life time of his father in 44 B.C in Rome. Heinen, H., Kleopatra- Studien, p. 247.

${ }^{130}$ Heinen, H., "Cäsar und Kaisareion", in: Historia (18), 1969, pp.181-203.

${ }^{131}$ The stela is now in Louvre Museum E. 27113. It is 52, $5 \mathrm{~cm}$ high, $28 \mathrm{~cm}$ wide and $4 \mathrm{~cm}$ thick. For the stela. Wagner, G., "Une Dédicacea la Grande Cleopatra de la Part du Synode Snonaitiaque", in: BIFAO (73), 1973, pp. 103-108, pl. IX; Bernand, E.,Recueil des Inscriptions Grecques du Fayoum, Tom. (III), la "Meris“ de Polemon, Leiden, 1981, p.205, pl.36, nr.205; id., Inscriptions Grecqués d'Egypte et de Nubie see du Louvre, Paris, 1992,pp.62-64, pl. 17.nr.21.

${ }_{132}$ Rowlandson, J., Women and Society in Greek and Roman Egypt, Cambridge,1998, p.38, fig.4.

${ }^{133}$ Bianchi, R., "Catalogue", in: Cleopatra's Egypt, pp.188-189, cat.78

${ }^{134}$ The stela is located now in Louvre in the department of the Egyptian Antiquities, E 20906 in Louvre Museum. Bernand, E., Inscriptions Grecqués de Fayoum,La "Méris" d'Herakleidès, Tom. (I), Paris, 1975, pl.9; id., Inscriptions Grecquésd'Egypte et de Nubie au Musée du Louvre,pp.61-62, pl. 16.nr.20.

${ }^{135}$ Ashton, S.,"Identifying the Egyptian - Style, Ptolemaic Queen“, in: Cleopatra of Egypt, p. 157, pl. 154.; Andrea, B., "Kleopatra und die historischen persönlichkeiten in ihrem Umkreis", in: Kleopatra und die Caesaren eine Ausstellung des Bucerius Kunst Forums, 28. Oktober 2006 bis 4.Februar2007, München,2006, p.60, kat.13.

${ }^{136}$ Rowlandson suggested that Cleopatra is depicted as a male- king in this stela. Rowlandson, J., Op. Cit, p. 38.

${ }^{137}$ Aston, S., "Identifying the Egyptian-style Ptolemaic queens", in: Cleopatra of Egypt from History to Myth, (ed. by Walker, S and Higgs, R), The British Museum Press, 2001, p. 157.

${ }^{138}$ Bernand, E., Inscriptions Graecques d'Egypte et de Nubie au Musée du Louvre, p. 63.

${ }^{139}$ Generini, F., "Cleopatra VII", in: Cleopatra, Roma e l'incantesimodee 'Egitto, Milano, 2013, p. 165, pl. 88.

${ }^{140}$ Klotz, D., Op. Cit, p. 245

${ }^{141}$ Dio Cassius.50.24.5-7; cf. 50.25-27.1.translation by Dundas, G., Pharaoh, Basileus and Imperator: The Roman Imperial Cult in Egypt, Ph.D unpublished. Diss.,Los Angeles, 1994.

${ }^{142}$ Diod.17,49, 2; Herod.3,16; Hemelrijk, E and Smelik, K., "Who knows Not What Monsters Demented Egyptian Worship", pp. 1927-1928. 
${ }^{143}$ Bosworth referred that Alexander the Great gave the homage before Apis, in reaction to the legendary story of Cambyses having slain the Apis bull on his arrival at Memphis. Bosworth, A., A Historical Commentary on Arrian's History of Alexander, Vol. (1), Oxford and New York, 1980, p. 262.

${ }^{144}$ Dio Cassius. 51. 16.5; Suetonius. 93; Herklotz, F., "AegyptoCapta, p. 13; Stadler, M., Egyptian Cult, Evidence from Temple Scriptoria and Christian Hagiographies", in: Oxford Handbook of Roman Egypt, p. 457.

${ }^{145}$ Stadler, M., Op. Cit, p. 457.

${ }^{146}$ Williams, J., Op. Cit, p195.

${ }^{147}$ Dio Cassius, 51,16.5, 17.4-5.

${ }_{148}$ McGann, M., "The Date of Tibullus' Death", in: Latomus (29/3), 1970, pp.774-780.

${ }^{149}$ Hemelrijk, E and Smelik, K., Op. Cit, p.1958.

${ }^{150}$ Grenier, J., “L'Empereur et le Pharaoh”, in: ANRW (II/ 18.5), Berlin, 1995, pp. 3182-3184;id., “L' Empereur et le Pharaoh”, in Egypte Romaine, l'autre Egypte, Musées de Marseille- Reunion des musées nationaux, Marseille, 1997, p. 38. Cambyses even summoned the Apisbull. He tried to stab him in the belly, but only wounded his thigh. He said to the priests " Do you call that a god, your poor blockheads? Are you gods' flesh and blood? Do they feel the pick of the steel? No doubt a god like that is good enough for the Egyptians; but you won't get away with trying to make a fool of me. Herod. 3.29; Schwartz, J., Les Conquérants Perses et la Littérature Egyptienne", in: BIFAO (48), 1949, p.68. See also Le Berre, E., " Le Taureau Apis. Un animal-dieudansl'enquêted' Hérodote", in: Religions Méditerranéennes et Orientales de l'Antiquité, Actes du Colloque des 23-24 avril 1999, (ed. by Labrique, F), IFAO, Le Caire, 2002, pp. 137148. The Apis bull was died later from his wound and was buried by the priests without the knowledge of Cambyses. Hemelrijk, E and Smelik, K ., Op. Cit, pp. 1864-1847; Pettigrew, T., A History of Egyptian Mummies and an account of the Worship and Embalming of the Sacred Animals by the Egyptians, Cambridge University Press, 2013, pp. 187188 .

${ }^{151}$ Bucheum 13=Kopenhagen, Ny Carlsberg Glyptothek AEIN 1681and Bucheum 14= Kairo JE 53142. See: Fairman, H., "The Hieroglyphic Inscriptions", in: The Bucheum II, (ed. by. Mond, R and Myers, O), EES Memoire (41, 2), London, 1934, pp. 13-14, pl. XLIII (13, 14) in: The Bucheum III. See Herklotz, F., Prinzeps und Pharao, pp. 134-135.

${ }^{152}$ The Buchis bull was the chief animal god of the entire Theban in late Period, it was characterized by having a white body and a black face. The living buchis was "herald of Re", while the mummified one was a manifestation of Osiris or Atum. Koltz, D., Op. Cit, pp.79-80.

${ }^{153}$ Pfeiffer, S., Der römische Kaise, p.51.

${ }^{154}$ Fairman, H., Op. Cit, in: The Bucheum (II), p. 32.

155 Although the Gallus stela did not mention Hermonthis among the five defeated towns.Dundas, G., Op. Cit, p. 73.

${ }^{156}$ Wilcken, U., "Octavian after the Fall of Alexandria”, in: JRS (27), 1937, p. 138.

${ }^{157}$ Fairman, H., Op. Cit, p.32.

${ }^{158}$ Apis was considered the incarnation of Ptah, that he is described in the journey of the sun-god Re in his barque as (Apis is Ptah, Apis is Re, Apis is Harsiese. Bonnet, H., "Apis", in:Lexikon der ägyptischen Religionsgeschichte, Hamburg, 2000, p.48. The connection of Apis with Ptah started from the N: K; the time of Ramses III. P. Harris I, 44, 9; Roeder, G., Die ägyptischeGötterwelt", in: Die Bibliothek der Alten Welt. Reihe der Alten Orient, Die ägyptische Religion in Texten und Bilden, (ed. By.Rüegg, W), Bd (1), Zürich, 1959, p. 51.

${ }^{159}$ The title of the high priest of Ptah, Petubastis in line $n^{0} .3$ in BM 188 is s3 s.t n Hp ${ }^{c} n h$ (Saset of the living Apis) Herklotz, F., Prinzeps und Pharao, pp. 133-134, note. 108.

${ }^{160}$ Herklotz, F.,Prinzeps und Pharao, p.296.

${ }^{161}$ Venit, M., Monumental Tombs of Ancient Alexandria, the Theater of the Dead, Cambridge University Press, 2002 , pp.142-143.

162 Dunand, F., Isis, Mere des Dieux, Paris, 2000, p. 122.

${ }^{163}$ Von Bissing, F., "EineApisfigure in der Haltung der Adlocutio", in: Oriental StudiesDedicated to Paul Haupt, (ed. by Adler, C and Ember, A), Baltimore: Johns Hopkins UniversityPress, p. 298; Zivie- Coche, C and Dunand, F., Die Religionen des AltenÄgypten, Stuttgart, 2013, p.95.

${ }^{164}$ Dunand, F., " Croyances et Rituels Funéraires, Les Images de l'Au-Dela: Vision Egyptienne et Vision Grecque", in: Hommes et Dieux en Egypte (300 a.c -395 p.c), (ed.by Dunand, F and Zivie- Coche, C), Paris, 2006, p.420.

${ }^{165}$ Malaise, M., Op. Cit, p. $248 f$.

${ }^{166}$ Hemelrijk, E. and Smelik, K., Op. Cit, p. 1929; Goldman, N., Op. Cit, p. 251.

${ }^{167}$ Dio 47.15.4, Green, L., Op. Cit, p.67.

168 Turcan, R., the Gods of Ancient Rome, p. 121.

${ }^{169}$ Lembke, L., Das Iseum Campense in Rom. Studien über den Isiskult unter Domitian, in: Archäologie un Geschichte (3), Heidelberg, 1994; Bommas, M., Forthcoming. "The IseumCampense as a lieu de memoire", in: Cultural Memory, Religion and the Ancient City (ed. by Bommas, M etal), London, 2011.

${ }^{170}$ Alfano, C., Op. Cit, p.285.

${ }^{171}$ Goldman, N., " Isis revealed: Cult and Costume in Italy", in: Archaeological Research in Roman Egypt, the Proceeding of the Seventeenth Classical Colloquium of the Department of Greek and Roman Antiquities, British Museum, JRA Supplementary Series (19), (ed. By M.Baily, D), Michigan, 1996, p.248. 
${ }^{172}$ Bricault, L., Myrionymi: Les Epiclèses Grecque et Latines d'Isis, de Sarapis et d'Anubis, Stuttgart, 1996.

${ }^{173}$ Klotz, D., Op. Cit, p.229

174 Turcan, R., the Cults of the Roman Empire, Oxford, 1997, p.87.

175 Pfeiffer, S., Der römische Kaiser.

${ }^{176}$ Green, L., Isis, the Egyptian Goddess Who Endured in the Graeco-Roman world", in: K.M.T (5), 1994, p.66.

${ }^{177}$ Claus, M., Kleopatra, München, 1995, p. 70, Abb.5. Arsinoe II is the first queen that identified herself as Isis is credited with introducing the worship of Isis to the Greek population of Egypt. Green, L., Op. Cit, p.62.

${ }^{178}$ Dio Cassius. 53.2, 4. Macrobius states the Octavian's attitude towards the Egyptian gods as " The Egyptians as they were not allowed by their religion to appease their gods with animals and blood-sacrifices but only with incense placed the temple extra promerium" Macrobius 1, 7: FRA 595, 15; Witt, R., Op. Cit, pp.223, 317 (note.7).

${ }^{179}$ Yehya, L., "Alexandria and Rome in Classical Antiquity. A Cultural Approach", in: Roma e l'Egitto, p. 358.

${ }^{180}$ Dio Cassius. 53.2, 4; 54.6,6.

${ }^{181}$ Green, L., Op.Cit, p. 67.

182 Ibid, pp.285-286.

${ }^{183}$ Turcan, R., Op. Cit, p.87.

${ }^{184}$ Dio Cassius, 54, 6, 6.

185 Yehya, L., Op. Cit, p. 358.

${ }^{186}$ In 20 B.C. G.Petronius decreed his "syntaxis" which reorganized the temples lands and treasures to be under the imperial control. It was a political and economic action to illuminate the power of the Egyptian priesthood and their richness. Augustus continued in the good treatment of the priests and supporting the temple building activities in Egypt and Nubia. Milne, J., A History of Egypt under the Roman Rule, $3^{\text {rd }}$. ed. London, 1924, pp.11-12.

${ }^{187}$ See: Buchner, E., Die Sonnenuhr des Augustus, Mainz, 1982.

${ }^{188}$ Green, L., Op. Cit, p.286.

${ }^{189}$ Depicted on the temples of Kalabscha and Phila.See: Heinen, H., Kleopatra- Studien, Gesammelte Schriften zur ausgehenden Ptolemäerzeit, Konstanz, 2009, pp.239, 242. He also depicted himself as the father of Caesarion in his stela which was depicted himself as a pharaoh is making offerings before the crocodile - god, Suchos, of Arsinoe. The stela is dedicated for Cleopatra by Augustus. About this stela see. Ibid, pp.244-248; id., "Julius Caesar als Vater des Ptolemaios XV. Kaiser (Kaisarion)", in: Vom hellenistischen Osten zum römischen Westen, Ausgewählte Schriften zur Alten Geschichte, Stuttgart, 2006, pp. 159-162.

${ }^{190}$ Klotz, D., Op. Cit, p. 231

${ }^{191}$ For the presence of Augustus at Kalabscha temple see. Herklotz, F., Prinzeps und Pharao: Der Kult des Augustus in Ägypten, pp. 151-155.

${ }_{192}$ Winter, E., Das Kalabscha- Tor in Berlin, Jahbuch Preußischer Kulturbesitz (14), 1979, pp.59-71.

${ }^{193}$ Winter, E., "Octavian/ Augustus alsSoter, Euergetesund Epiphanes: Die Datierung des Kalabscha- Tores", in: ZÄS (130), 2003, pp.197-212; Grenier, J., Les titulatatures des empereurs romains dans les Documents en Langue egyptienne, PapBrux (22), Bruxelles, 1989, p.17, no.7; Cauville, S., L'Impossible serrement de main ou le Pax romana a Dendera“, in: RdE (58), 2007, p.32.

${ }^{194}$ Capponi, L., Augustan Egypt, the Creation of a Roman Province, New York, 2005.

${ }^{195}$ Winter, E., Op. Cit, in: Z̈̈S (130), 2003, pp.197-212.

${ }^{196}$ Ibid, p.200, pl. XLVI.

${ }^{197}$ Minas- Nerpel, M and Pfeiffer, S., Op. Cit, pp.274-275.

${ }^{198}$ Herklotz, F., Prinzeps und Pharao, p. 154.

199 For the presence of Augustus at Phila see. Herklotz, F., Prinzeps und Pharao, pp.160-165.

${ }^{200}$ About the mammisi of Phila see: Junker, H and Winter, E., Das Geburtshaus des Tempels der Isis in Philä, Wien, 1965 , p. 256 f. the lines 17-21 of the text from south.

${ }^{201}$ Heine, H., " Vorstufen und Anfänge der Herrscherkultes im römischen Ägypten(Aufsteige und Niedergang der römischen Welt, Bd. II 18, 5, Berlin, New York, 1995", in: Vom hellenistischen Osten zum römischen Westen, Ausgewählte Schriften zur Alten Geschichte, (ed. By.Binsfeld, A and Pfeiffer, S), Stuttgart, 2006, p.198, Taf. XII.

${ }^{202}$ Benedite, G., Philae, Bd. 1, MMAF (13), Paris, 1895, pp. 97, 101; Herkltz, F., Prinzeps und Pharao, p. 162, note. 263.

${ }^{203}$ PM. 6, p.246, Nr. 383f; Benedite, G., Op. Cit, p. 83, pl. 27.

${ }^{204}$ The temple was built by Ptolemy Vi and Ptolemy VIII.

${ }^{205}$ Dumas, F., Les Propylees du Temple d' Hathor a Phila et le Culte de la Deese", in: ZÄS 8’(95), 1968, p. 1; Hölbl, G., Die Tempel des römischen Nubien, Mainz, 2004, p. $18 f$. 